\title{
Radiative efficiencies for fluorinated esters: indirect global warming potentials of hydrofluoroethers
}

Article

Accepted Version

Bravo, I., Diaz-de-Mera, Y., Aranda, A., Moreno, E., Nutt, D. and Marston, G. (2011) Radiative efficiencies for fluorinated esters: indirect global warming potentials of hydrofluoroethers. Physical Chemistry Chemical Physics, 13 (38). pp. 1718517193. ISSN 1463-9076 doi:

https://doi.org/10.1039/C1CP21874C Available at https://centaur.reading.ac.uk/25663/

It is advisable to refer to the publisher's version if you intend to cite from the work. See Guidance on citing.

To link to this article DOI: http://dx.doi.org/10.1039/C1CP21874C

Publisher: Royal Society of Chemistry

All outputs in CentAUR are protected by Intellectual Property Rights law, including copyright law. Copyright and IPR is retained by the creators or other copyright holders. Terms and conditions for use of this material are defined in the End User Agreement. 


\section{CentAUR}

Central Archive at the University of Reading

Reading's research outputs online 


\section{Radiative Efficiencies for Fluorinated Esters: Indirect 2 Global Warming Potentials of Hydrofluoroethers}

3 Iván Bravo ${ }^{1}$, Yolanda Díaz-de-Mera ${ }^{2}$, Alfonso Aranda ${ }^{2}$, Elena Moreno ${ }^{2}$, David R. $\mathrm{Nutt}^{3}$ and George

4 Marston $^{3}$

5

${ }^{1}$ Instituto de Ciencias Ambientales (ICAM), Universidad de Castilla La Mancha, Avenida Carlos III, s/n, 45071 Toledo, Spain.

${ }^{2}$ Physical Chemistry Department, University of Castilla-La Mancha, Chemistry Faculty, Avda. Camilo Jose Cela 10, 13071 Ciudad Real, Spain.

${ }^{3}$ Department of Chemistry, University of Reading, Whiteknights PO Box 224, Reading RG6 6AD, UK.

* Author to whom correspondence should be addressed:

Phone: +34 925268800. Ext: 5790. E-mail: ivan.bravo@uclm.es

\section{Abstract}

Density Functional Theory (DFT) has been used with an empirically-derived correction for the wavenumbers of vibrational band positions to predict the infrared spectra of several fluorinated esters (FESs). Radiative efficiencies (REs) were then determined using the Pinnock et al. method and these were used with atmospheric lifetimes from the literature to determine the direct global warming potentials of FESs. FESs, in particular fluoroalkylacetates, alkylfluoroacetates and fluoroalkylformates, are potential greenhouse gases and their likely long atmospheric lifetimes and relatively large REs, compared to their parent HFEs, make them active contributors to global warming. Here, we use the concept of indirect global warming potential (indirect GWP) to assess the contribution to the warming of several commonly used HFEs emitted from the Earth's surface, explicitly taking into account that these HFEs will be converted into the corresponding FESs in the troposphere. The indirect GWP can be calculated using the radiative efficiencies and lifetimes of the HFE and its degradation FES products. We found that the GWPs of the HFEs studied can be increased by $100-1600 \%$ when taking account of the cumulative effect due to the secondary FESs formed during HFE atmospheric oxidation. This effect may be particularly important for non-segregated HFEs and some segregated HFEs, which may contribute significantly more to global warming than can be concluded from examination of their direct GWPs. 


\section{Introduction}

Hydrofluoroethers (HFEs) are being used as chlorofluorocarbon (CFC), hydrochlorofluorocarbon (HCFC), hydrofluorocarbon (HFC) and perfluorocarbon (PFC) replacements in a number of industrial applications, such as their use as cleaning solvents, heat transfer agents in refrigeration, carrier fluids or even as anaesthetic agents in the pharmaceutical industry. ${ }^{[1],[2],[3]}$ These HFEs possess zero ozone depletion potentials since they do not contain $\mathrm{Cl}$ atoms. HFEs were designed to react easily with $\mathrm{OH}$ radicals in the troposphere because of the inclusion of $\mathrm{H}$ atoms in the structure, which minimizes their contribution to global warming. Several studies have been carried out to determine the impact that HFEs have on climate, through the measurement of infrared spectra, atmospheric lifetimes $(\tau)$, radiative efficiencies (REs) and global warming potentials (GWPs) (see e.g. Sihra et al, 2001 ${ }^{[4]}$ and Bravo et al., 2010 $0^{[5]}$ ). However, although HFEs may be destroyed relatively quickly in the atmosphere, this process does not remove the C-F bonds, which can still absorb IR radiation and stay in the troposphere for longer periods of time. It is important therefore to understand the mechanisms of HFE oxidation in the atmosphere and the impact on climate of their degradation products.

It is well known that fluorinated esters (FESs) are the primary products of the atmospheric oxidation of HFEs (see e.g. Wallington et al. $1997^{[6]}$, Christensen et al. $1998^{[7]}, 1999^{[8]}$; Ninomiya et al., 2000 ${ }^{[9]}$ and Oyaro et al., $2004^{[10]}$ ). Like most organic compounds, FESs containing C-H bonds are removed from the troposphere by reactions with atmospheric oxidants, with reaction with $\mathrm{OH}$ radicals being their primary removal process. ${ }^{[1],[12],[13],[14]}$ Dissolution in seawater and clouds has been considered a potentially significant sink since some FESs are known to be readily hydrolyzed. ${ }^{[15]}$ However, there are insufficient Henry's Law and solubility data available for FESs to fully assess this loss process. Some recent studies have revealed that dissolution in clouds might not be an important atmospheric sink for FESs whereas dissolution in oceans could be a more efficient pathway. ${ }^{[16]}$ This means that wet deposition in clouds is perhaps not such an important sink as previously believed and FESs will remain in the troposphere until they are removed by $\mathrm{OH}$ or are dissolved in the ocean. Taking into account the fact that other chemical degradation processes such as reactions with $\mathrm{Cl}, \mathrm{NO}_{3}$ or $\mathrm{O}_{3}$, along with photolysis, are considered to be unimportant atmospheric degradation pathways for FESs, ${ }^{[14], ~[15] ~}$ their tropospheric lifetimes are expected to be determined mainly by $\mathrm{OH}$ radicals.

The atmospheric oxidation of HFEs will lead to different sets of FESs depending on the parent HFE molecule. For segregated HFEs, in which the perfluorinated part of the molecule is separated from the fully hydrogenated part by the ether oxygen $\left(\mathrm{R}_{\mathrm{H}} \mathrm{OR}_{\mathrm{F}}\right)$, segregated fluorinated esters are the primary oxidation products. For instance, the perfluoroakylformates $\mathrm{C}_{4} \mathrm{~F}_{9} \mathrm{OC}(\mathrm{O}) \mathrm{H}$ and $n-\mathrm{C}_{3} \mathrm{~F}_{7} \mathrm{OC}(\mathrm{O}) \mathrm{H}$ are the major degradation products of HFE-7100 $\left(\mathrm{C}_{4} \mathrm{~F}_{9} \mathrm{OCH}_{3}\right)$ and HFE-7000 $\left(\mathrm{C}_{3} \mathrm{~F}_{7} \mathrm{OCH}_{3}\right)$, respectively. ${ }^{[6], ~[9] ~}$ 
On the other hand, the perfluoroalkylacetate $\mathrm{C}_{4} \mathrm{~F}_{9} \mathrm{OC}(\mathrm{O}) \mathrm{CH}_{3}$ is the major product for HFE-7200 $\left(\mathrm{C}_{4} \mathrm{~F}_{9} \mathrm{OCH}_{2} \mathrm{CH}_{3}\right){ }^{[7]}$ Non-segregated HFEs have hydrogen and/or fluorine atom on both sides of the ether link, and their oxidation products depend on which $\mathrm{H}$ atom can be more easily abstracted. For example, Chen et al. ${ }^{[13]}$ reported $\mathrm{CF}_{3} \mathrm{CHFOC}(\mathrm{O}) \mathrm{H}$ and the alkylfluoroformate $\mathrm{FC}(\mathrm{O}) \mathrm{OCH}_{3}$ as the primary oxidation products of $\mathrm{CF}_{3} \mathrm{CHFOCH}_{3}$. Other groups have reported alkyl and fluoroalkylfluoroacetates in the $\mathrm{HFE}$ atmospheric oxidation, e.g. $\mathrm{CH}_{3} \mathrm{OC}(\mathrm{O}) \mathrm{CF}_{3}$ from $\mathrm{CH}_{3} \mathrm{OCH}\left(\mathrm{CF}_{3}\right)_{2}$ oxidation ${ }^{[17]}$ or $\mathrm{CF}_{3} \mathrm{C}(\mathrm{O}) \mathrm{OCHF}_{2}$ from $\mathrm{CF}_{3} \mathrm{CHClOCHF}_{2}$ oxidation. ${ }^{[18]}$ Lastly, some product distribution studies have shown that the FES oxidation leads to the formation of fluorinated acetic acid and the corresponding anhydrides along with $\mathrm{CF}_{2} \mathrm{O}$ and its hydrolysis products $\mathrm{CO}_{2}$ and $\mathrm{HF} .{ }^{[19], ~[18], ~[20] ~}$

It is important to assess the environmental compatibility of new chemical compounds and to have an understanding of their impact on global warming. In order to achieve this, it is not enough simply to focus on the radiative properties of the parent compound. It is also important to consider oxidation mechanisms and the radiative properties of stable intermediate products in order to assess their impact on global warming. At present, there are no determinations of REs or GWPs for FESs from direct measurements. In the present study we examine these properties on the basis of previous theoretical and experimental work from our laboratories on the REs and GWPs of HFEs ${ }^{[5], ~[21] ~}$ and PFCs ${ }^{[22]}$. In our publication on PFCs, we reported a theoretical method for determining infrared spectra and REs (and hence GWPs where an atmospheric lifetime was known or could reasonably be inferred). The calculated RE is extremely sensitive to the exact position of the C-F stretch at around $1250 \mathrm{~cm}^{-1}$ and the raw calculated frequencies cannot be used directly in radiative transfer models. Thus, we used a combination of theoretical and experimental results to obtain a very precise correction to the band position generated directly from the density functional theory (DFT) or $a b$ initio calculations. Furthermore, in subsequent work ${ }^{[21]}$, we extended and tested the method for HFEs and hydrofluoropolyethers (HFPEs). The results showed that the method gave predictions in very good agreement with experimental values. One of the aims of the present study is to apply this method to calculate IR spectra and REs for FESs and to predict these quantities for a range of related compounds. This is the first study to report data of cross sections, REs and GWPs for FESs. The FESs studied belong to the series fluoroakylformates, fluoroalkylacetates, fluoroalkylfluoroformates, and fluoroalkylfluoroacetates.

\section{Methodology}

Radiative forcing per unit concentration change or radiative forcing efficiency, is a fundamental parameter which measures the change in the Earth's radiation balance for a 1 ppbv increase in concentration of the greenhouse gas. For any gas, this efficiency depends on the spectral variation of 
the absorption cross-section, as the energy available to be absorbed in the atmosphere depends on this via both the Planck function and the absorption spectra of other species in the atmosphere [see e.g. Pinnock et al., $1995^{[23]}$. Pinnock et al. ${ }^{[23]}$ created a simple model for radiative forcing that allows the straightforward determination of the radiative efficiency, $R E$, of a gas from its experimentally measured infrared spectrum without the use of a complex radiative transfer model. In this approach, the $R E$ is given by:

$$
R E=\sum_{i=1}^{250} 10 \bar{\sigma}_{i}\left(\bar{v}_{i}\right) F_{i}\left(\bar{v}_{i}\right)
$$

where $\overline{\sigma_{i}}\left(\overline{v_{i}}\right)$ is the absorption cross section in $\mathrm{cm}^{2}$ molecule ${ }^{-1}$ averaged over a $10 \mathrm{~cm}^{-1}$ interval around the wavenumber $\bar{v}_{i}$, and $F_{i}\left(\bar{v}_{i}\right)$ is the instantaneous, cloudy sky, radiative forcing per unit cross section in $\mathrm{W} \mathrm{m}^{-2}\left(\mathrm{~cm}^{2} \text { molecule }{ }^{-1} \mathrm{~cm}^{-1}\right)^{-1}$ for a 0 to 1 ppbv increase in absorber. The values for $F_{i}\left(\bar{v}_{i}\right)$ as a function of wavenumber were determined by Pinnock et al. ${ }^{[23]}$ using their narrowband radiative transfer model. This expression can be applied directly to experimentally determined infrared absorption cross sections.

The methods used here for the calculation of infrared spectra, REs and GWPs have been described elsewhere ${ }^{[22],[21]}$ but are briefly set out here. The Gaussian03 software package ${ }^{[24]}$ was used to perform the computational calculations. Molecular structures were first optimized at B3LYP/6-31G** level of theory, followed by calculation of vibrational frequencies. No symmetry constraints were imposed and, for all molecules, the absence of negative frequencies confirmed that we had obtained a minimum on the potential energy surface. When more than one minimum was found, the structure with the lowest Gibbs free energy was used for the calculation of radiative efficiencies. Accurate REs can only be obtained for fluorinated compounds if the position of the main C-F stretching vibrational mode is determined very precisely. Following our previous work ${ }^{[22],[21]}$ we use the expression $\bar{v}_{\text {scal }}=$ $0.977 \bar{v}_{\text {calc }}+11.664 \mathrm{~cm}^{-1}$ to obtain scaled wavenumbers that are used for the RE calculations. Other groups ${ }^{[25],[26]}$ have used similar approaches, although usually using a generic correction factor.

Furthermore, since the theoretical calculations-provide integrated cross sections, $A_{\mathrm{i}}$, (in $\mathrm{cm}^{2}$ molecule ${ }^{-1}$ $\mathrm{cm}^{-1}$ ) for each vibrational mode at a precise wavenumber, these data can be converted into average cross sections over $10 \mathrm{~cm}^{-1}$ intervals simply by dividing by $10 \mathrm{~cm}^{-1}$. The obtained data are then used to calculate radiative efficiencies and global warming potentials. The overall integrated cross section, $S_{\text {calc }}$ is simply the sum of the $A_{i}$ over the appropriate wavenumber range. 
Having calculated REs, GWPs over a variety of time horizons can be determined relative to carbon dioxide if the lifetime for the FESs is known or can be estimated (see e.g. IPCC (2007) ${ }^{[27]}$ )

\section{Results and Discussion.}

In this section we present integrated cross sections, REs and GWPs obtained for several fluorinated esters. The FESs expected from the tropospheric oxidation of HFEs may be classified as: fluoroakylformates, $\mathrm{HC}(\mathrm{O}) \mathrm{O}-\mathrm{R}_{\mathrm{F}}$, fluoroalkylacetates $\mathrm{CH}_{3}-\mathrm{C}(\mathrm{O}) \mathrm{O}-\mathrm{R}_{\mathrm{F}}$, fluoroalkylfluoroformates $\mathrm{FC}(\mathrm{O}) \mathrm{O}-\mathrm{R}_{\mathrm{F}}$, and fluoroalkylfluoroacetates $\mathrm{CF}_{3}-\mathrm{C}(\mathrm{O})-\mathrm{O}-\mathrm{R}_{\mathrm{F}}$ where $\mathrm{R}_{\mathrm{F}}$ is an alkyl chain with at least one $\mathrm{F}$ atom.

\subsection{Infrared Absorption Cross Sections and Radiative Efficiencies}

Only a few studies have reported experimental infrared spectra for FESs. These show that FESs are potentially greenhouse gases since they absorb infrared radiation strongly between 1000 and $1400 \mathrm{~cm}^{-}$ ${ }^{1}[28],[9],[20],[18]$ None of these studies reported integrated cross section data. Our integrated absorption cross sections, $S_{\text {calc }}$, calculated between 0 and $2500 \mathrm{~cm}^{-1}$ using B3LYP/6-31G**, are presented in Table 1. (The predicted infrared spectra are presented in the supplementary material).

To the best of our knowledge, measurements of REs for FESs have not been reported in the literature. We have used our theoretically determined spectra to calculate REs using the Pinnock et al. ${ }^{[23]}$ method as described above in section 2. Predicted REs are summarized in Table 2, where they are compared with previously reported values for the parent HFE. We can see in this table that the majority of FESs posses larger REs than their parent HFEs, even when they have the same number of C-F bonds in the molecular structure. For instance, this is observed in the following selected FES vs HFE couples (REs in $\mathrm{W} \mathrm{m}{ }^{-2} \mathrm{ppbv}^{-1}$ given in parentheses): $\mathrm{HC}(\mathrm{O}) \mathrm{OCF}_{2} \mathrm{CF}_{2} \mathrm{CF}_{3}$ vs. $\mathrm{CH}_{3} \mathrm{OCF}_{2} \mathrm{CF}_{2} \mathrm{CF}_{3}$ (0.55 vs. 0.37); $\mathrm{CH}_{3} \mathrm{C}(\mathrm{O}) \mathrm{OCF}_{2} \mathrm{CF}_{2} \mathrm{CF}_{2} \mathrm{CF}_{3}$ vs. $\mathrm{C}_{2} \mathrm{H}_{5} \mathrm{OC}_{4} \mathrm{~F}_{9}$ (0.66 vs. 0.42); $\mathrm{CF}_{3} \mathrm{C}(\mathrm{O}) \mathrm{OCH}_{2} \mathrm{CF}_{3}$ vs. $\mathrm{CF}_{3} \mathrm{CH}_{2} \mathrm{OCH}_{2} \mathrm{CF}_{3}$ (0.41 vs. 0.33), where FESs have significantly larger REs than their corresponding fluorinated ethers. This can be simply rationalized if we consider that the infrared cross section spectrum depends strongly on the nature of the molecular structure. This is illustrated in Figure 1 for the infrared spectra of $\mathrm{CH}_{3} \mathrm{OCF}_{2} \mathrm{CF}_{2} \mathrm{CF}_{3}$ (HFE-7000) and $\mathrm{HC}(\mathrm{O}) \mathrm{OCF}_{2} \mathrm{CF}_{2} \mathrm{CF}_{3}$. The ester, compared to the ether, has an additional strong band in the $1100 \mathrm{~cm}^{-1}$ region of the spectrum where the radiative forcing function is large. This feature can be assigned to the $\mathrm{C}-\mathrm{O}-\mathrm{C}(\mathrm{O}) \mathrm{R}$ stretch that occurs in these molecules.

The relationship between the REs and molecular structure has been investigated in previous studies by examining how the integrated cross section and REs vary with the number of C-F bonds in the molecule. ${ }^{[25],[29],[22]}$ Figures 2 and 3 show the dependences on the number of C-F bonds of integrated cross section and REs of the studied compounds. The REs clearly increase with the number of C-F bonds. Slightly different REs are found for the different structures of FESs, fluoroakylformates, 
$\mathrm{HC}(\mathrm{O}) \mathrm{O}-\mathrm{R}_{\mathrm{F}}$, fluoroalkylacetates $\mathrm{CH}_{3}-\mathrm{C}(\mathrm{O}) \mathrm{O}-\mathrm{R}_{\mathrm{F}}$, fluoroalkylfluoroformates $\mathrm{FC}(\mathrm{O}) \mathrm{O}-\mathrm{R}_{\mathrm{F}}$, and fluoroalkylfluoroacetates $\mathrm{CF}_{3}-\mathrm{C}(\mathrm{O})-\mathrm{O}-\mathrm{R}_{\mathrm{F}}$. . In Figure 3, we compare the $\mathrm{RE}$ obtained for FESs with those obtained using the same approaching for PFCs and HFEs in our previous publications. ${ }^{[22],[21]}$. Here we see that FESs have greater radiative efficiencies than HFEs and PFCs with the same number of C-F bonds. This observation is supported by other authors who have explained it in terms of the greater contribution of $\mathrm{C}-\mathrm{F}$ bonds adjacent to $\mathrm{O}$ atoms to the overall RE. ${ }^{[29],[27]}$ This is illustrated in the series $\mathrm{C}_{3} \mathrm{~F}_{8}(0.27), \mathrm{c}_{4} \mathrm{C}_{4} \mathrm{~F}_{8}(0.30), \mathrm{FC}(\mathrm{O}) \mathrm{OCF}_{2} \mathrm{CF}_{2} \mathrm{CF}_{3}(0.51)$ and $\mathrm{CF}_{3} \mathrm{C}(\mathrm{O}) \mathrm{OCF}_{2} \mathrm{CF}_{3}(0.59)$ or in the series $\mathrm{CF}_{4}(0.08), \mathrm{CH}_{3} \mathrm{OCF}_{2} \mathrm{CF}_{2} \mathrm{H}(0.28), \mathrm{FC}(\mathrm{O}) \mathrm{OCF}_{3}(0.31)$ and $\mathrm{HC}(\mathrm{O}) \mathrm{OCHFCF}_{3}(0.38)$ for 8 and 4 $\mathrm{C}-\mathrm{F}$ bonds, respectively, with the $\mathrm{RE}$ in $\mathrm{W} \mathrm{m}^{-2} \mathrm{ppbv}^{-1}$ given in parentheses.

Furthermore, when we compare fluoroakylformates with alkylfluoroformates, species with similar molecular structure, we can observe that fluoroalkylformate have very similar REs to the analogous alkylfluoroformates even though these compounds have one more $\mathrm{F}$ atom in the structure. For example, this effect is observed for $\mathrm{HC}(\mathrm{O}) \mathrm{OCF}_{3}, \mathrm{HC}(\mathrm{O}) \mathrm{OCF}_{2} \mathrm{CF}_{3}$ and $\mathrm{HC}(\mathrm{O}) \mathrm{OCF}_{2} \mathrm{CF}_{2} \mathrm{CF}_{3}$ which have REs similar to $\mathrm{FC}(\mathrm{O}) \mathrm{OCF}_{3}, \mathrm{FC}(\mathrm{O}) \mathrm{OCF}_{2} \mathrm{CF}_{3}$ and $\mathrm{FC}(\mathrm{O}) \mathrm{OCF}_{2} \mathrm{CF}_{2} \mathrm{CF}_{3}$, respectively. A different effect is observed for the integrated cross section values. In this case, the effect of molecular structure is almost the opposite to the observations for radiative efficiencies values. This can be explained simply since alkylfluoroformates have one extra C-F bonds in the molecular structure compared with their corresponding fluoroakylformates, and this leads to an increase in the integrated cross section of the molecule. This extra $\mathrm{F}$ atom, which is bonded to the carbonyl $\mathrm{C}$ atom, is separated from the fluoroalkyl chain, and the C-F stretching vibration is located at around $1900 \mathrm{~cm}^{-1}$. The radiative forcing function is small in this spectral region and therefore its contribution to the overall REs in the molecule is negligible. An analogous situation arises for bands associated with the carbonyl groups in all FESs; these bands are observed at about $1800 \mathrm{~cm}^{-1}$ and so make only a small contribution to the RE.

\subsection{Implications for Atmospheric Chemistry and some Global Warming highlights.}

\section{Atmospheric fate of fluorinated esters}

As mentioned above, it is well-known that hydrofluorinated esters (FESs) are the primary products of the atmospheric oxidation of hydrofluoroethers. However, there is a lack of knowledge about their atmospheric fate. Since esters and some FESs are known to be easily hydrolyzed, it is often assumed that they are easily removed through wet deposition, as is the case for hydrogenated carbonyl compounds. However, recent studies have shown that wet deposition might not be an important sink for all FESs and the $\mathrm{OH}$ initiated oxidation determines the atmospheric lifetimes of some of them. ${ }^{[30],[11],[12],[13],[14],[16]}$ In the work of Kutsuna et al. ${ }^{[16]}$, the Henry's law constants and hydrolysis rate 
constants are reported for the fluoroalkylacetate $\mathrm{CH}_{3} \mathrm{C}(\mathrm{O}) \mathrm{OCH}_{2} \mathrm{CF}_{3}$ and for the alkylfluoroacetate $\mathrm{CF}_{3} \mathrm{C}(\mathrm{O}) \mathrm{OCH}_{3}$ along with their lifetimes through dissolution in clouds and oceans. They found that dissolution in clouds is not a significant atmospheric sink for either $\mathrm{CH}_{3} \mathrm{C}(\mathrm{O}) \mathrm{OCH}_{2} \mathrm{CF}_{3}$ or $\mathrm{CF}_{3} \mathrm{C}(\mathrm{O}) \mathrm{OCH}_{3}$, and only dissolution in ocean water could be significant. In the same study, they examined the effect of fluorination in esters and observed that fluorination drastically decreased the solubility of the fluorinated esters $\mathrm{CH}_{3} \mathrm{C}(\mathrm{O}) \mathrm{OCH}_{2} \mathrm{CF}_{3}(0.58)$ and $\mathrm{CF}_{3} \mathrm{C}(\mathrm{O}) \mathrm{OCH}_{3}(0.12)$ compared to the similar non-fluorinated esters $\mathrm{CH}_{3} \mathrm{C}(\mathrm{O}) \mathrm{OCH}_{2} \mathrm{CH}_{3}$ (5.9) and $\mathrm{CH}_{3} \mathrm{C}(\mathrm{O}) \mathrm{OCH}_{3}$ (7.8), with Henry's law constants in $\mathrm{M} \mathrm{atm}^{-1}$ at $298 \mathrm{~K}$ in parentheses. Therefore, reaction with the $\mathrm{OH}$ radical seems to be the main degradation pathway for fluoroalkylacetates and alkylfluoroacetates. It is important to note that some of these species have relatively long lifetimes with respect to reaction with $\mathrm{OH}$ radicals, with values between $1-4$ months. This is shown in Table 3 where some $\mathrm{OH}$ lifetimes found in the literature are summarized for the FESs studied in the present work. It is clear from this table that the lifetimes of FESs in the atmosphere have not been comprehensively studied. For alkylfluoroformates, the lifetime with respect to reaction with $\mathrm{OH}$ radicals has only been reported for $\mathrm{FC}(\mathrm{O}) \mathrm{OCH}_{3}$ (1.8 yrs). However, some studies show that halocarbonyl and haloacetic halide $(\mathrm{R}-\mathrm{C}(\mathrm{O}) \mathrm{F})$ compounds have high values of the Henry's law constants and may be removed easily by wet-deposition, ${ }^{[31]}$ and this indicates that alkylfluoroformates in general may behave in this way, in contrast to the behaviour observed for fluoroalkylacetates and alkylfluoroacetates. Up to now, there are no gas-to-water equilibrium data for fluoroalkylformates in the literature. It is expected that they will be removed from the atmosphere by wet-deposition by analogy with the non-fluorinated formates (see e.g. Wallington et al., (1998) ${ }^{[32]}$; Oyaro et al., (2004) ${ }^{[10]}$ ). Nevertheless, the highly fluorinated nature of the segregated compounds may decrease their solubility in water and their removal in the atmosphere through reaction with $\mathrm{OH}$ radicals may be significant for fluoroalkylformates.

Furthermore, other studies indicate that photolysis of esters is not relevant in the troposphere and the volatility of the compounds will probably render the atmospheric removal through dry deposition mechanisms unlikely. ${ }^{[10],[14]}$ Finally, the oxidation of FESs leads mainly to the formation of the fluorinated acids and anhydrides along with $\mathrm{CF}_{2} \mathrm{O}, \mathrm{CO}_{2}$ and $\mathrm{HF}$ which are the hydrolysis products. Acids and anhydrides are very soluble compounds and will be rapidly incorporated into clouds droplets. ${ }^{[14],[19],[33]}$

What is clear from this background is that the atmospheric lifetime for a lot of FESs is determined mainly by $\mathrm{OH}$ initiated oxidation and further investigation of the atmospheric fate of FESs is needed. In summary, FESs, in particular fluoroalkylacetates, alkylfluoroacetates and fluoroalkylformates, are potential greenhouse gases and their likely long atmospheric lifetimes and relatively larger REs, compared to their parent HFEs, make them active contributors to global warming. 
230

231

232

233

234

235

236

237

238

239

240

241

242

243

244

245

246

247

248

249

250

251

252

253

254

255

256

257

258

259

The GWP is one possible climate metric to place emissions on a $\mathrm{CO}_{2}$-equivalent scale and we present GWPs for consistency with the earlier literature. The GWP concept takes into account both the RE and the lifetime of a gas. It is therefore defined as the radiative forcing of an emission of $1 \mathrm{~kg}$ of some compound at time zero, integrated over some given time horizon, divided by the same value for a $1 \mathrm{~kg}$ emission of carbon dioxide. The method used here is described at length in IPCC, 2007.

The predicted REs reported in this work along with absolute GWP for carbon dioxide and the atmospheric lifetimes can then be used to obtain the GWPs over 20, 100 and $500 \mathrm{yr}$ time horizons. In Table 3, we present the atmospheric lifetimes with respect to $\mathrm{OH}$ radicals reported in literature. For some of the compounds, lifetimes have not been reported, but we can make estimates based on the behaviour of analogous compounds. For GWP calculations we consider $\mathrm{OH}$ oxidation to be the main tropospheric degradation pathway for selected FESs. We expect this to be valid for fluoroalkylacetates, alkylfluoroacetates and fluoroalkylformates, as discussed earlier. We report RE values from the adopted method of Pinnock et al. ${ }^{[23]}$ in section 3.1, assuming the compounds are wellmixed in the atmosphere; however, the relatively short-lived species discussed here are unlikely to be well-mixed, and in particular their mixing ratios will fall off rapidly in the stratosphere. The actual distribution would likely depend on the location of the emissions from the Earth surface which would require sophisticated chemical-transport model calculations to ascertain. ${ }^{[4]}$ This methodology will be necessary when the gas is emitted directly from the surface and then lifetime-corrections are needed.

The assessment of the contribution to the warming of a given HFE emitted from the Earth's surface should consider that this HFE will be converted into the corresponding FES in the troposphere. The new products have a cumulative contribution to the total absorption of radiation due to the emissions of the primary pollutants. Here we calculate the net global warming potential of the parent HFE as the sum of the direct HFE global warming and the indirect contributions due to the corresponding products (FESs). Here, we obtain the contribution of secondary products from their radiative efficiencies and their atmospheric time profiles:

$$
\mathrm{HFE}+\mathrm{OH} \rightarrow \mathrm{FES}
$$

$$
\mathrm{FES}+\mathrm{OH} \rightarrow \text { Products }
$$

For such a pair of consecutive reactions - assuming pseudo-first-order conditions - the time profile of a given FES for a pulse of HFE is:

$$
[F E S](t)=[H F E]_{0} \frac{k_{1}}{k_{2}-k_{1}}\left(e^{-k_{1} t}-e^{-k_{2} t}\right)
$$


where $k_{1}$ and $k_{2}$ are the rate constants toward $\mathrm{OH}$ radicals multiplied by the average $\mathrm{OH}$ radical concentrations.

The term:

$$
\alpha \frac{\int_{0}^{h} R E(F E S)[F E S](t) d t}{\int_{0}^{h} R E\left(C O_{2}\right)\left[C O_{2}\right](t) d t}
$$

where $\alpha$ is the yield of a given FES, gives the contribution of such species to the net GWP of the parent HFE. Since the FESs studied here come from the atmospheric oxidation of their parent HFEs, which are supposed to possess a uniform vertical distribution through the troposphere, we also assume that FESs are well-mixed species.

The substitution of (II) into (III) and the following integrations gives equation (IV) which evaluates the indirect GWP of a determined HFE over a time horizon th due to its corresponding oxidation product $i$ :

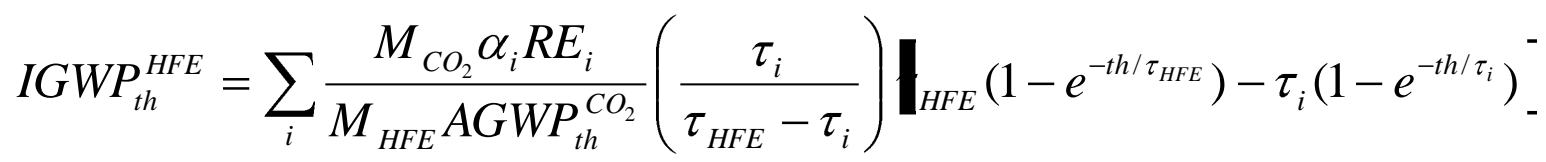

where $A G W P_{t h}^{\mathrm{CO}_{2}}$ is the absolute GWP for $\mathrm{CO}_{2}$ at the time horizon $t h$ in $\mathrm{W} \mathrm{m}^{-2} \mathrm{yr} \mathrm{ppmv}^{-1}, M_{\mathrm{CO}_{2}}$ and $M_{H F E}$ are the molecular weights of $\mathrm{CO}_{2}$ and the parent HFE, respectively, $R E_{i}$ is the radiative efficiency of the product $i$ (in $\mathrm{W} \mathrm{m}^{-2} \mathrm{ppmv}^{-1}$ ); and $\tau_{H F E}$ and $\tau_{i}$ are the lifetimes of the parent HFE and the species $i$, respectively, obtained as $\tau=\frac{1}{k[O H]}$.

The net GWP will be the sum of the direct and indirect GWP:

$n e t-G W P_{t h}^{H F E}=\frac{M_{C O_{2}} \tau_{H F E}\left(1-e^{-t h / \tau_{H F E}}\right)}{M_{H F E} A G W P_{t h}^{C O_{2}}}\left[R E_{H F E}+\sum_{i} \frac{\alpha_{i} R E_{i} \tau_{i}}{\tau_{H F E}-\tau_{i}}\left(1-\frac{\tau_{i}\left(1-e^{-t h / \tau_{i}}\right)}{\tau_{H F E}\left(1-e^{-t h / \tau_{H F E}}\right)}\right)\right]$

Direct, indirect and net-GWPs for some common HFEs are summarized in Table 4. Figure 4 shows the behaviour of the direct and net-GWP for three compounds whose oxidations lead to different FESs: 
HFE-7200 $\left(\mathrm{C}_{4} \mathrm{~F}_{9} \mathrm{OC}_{2} \mathrm{H}_{5}\right)$, HFE-7000 $\left(\mathrm{C}_{3} \mathrm{~F}_{7} \mathrm{OCH}_{3}\right)$ and $\left(\mathrm{CF}_{3}\right)_{2} \mathrm{CHOCH}_{3}$. In this Figure, the $A G W P_{\text {th }}^{C O_{2}}$ at each time horizon was calculated using the IPCC, $2007^{[27]}$ expression, where $R F_{\mathrm{CO}_{2}}=0.01413 \mathrm{~W} \mathrm{~m}^{-}$ ${ }^{2} \mathrm{ppm}^{-1}$ and the decay of a pulse of $\mathrm{CO}_{2}$ with time $t$ is given by $a_{0}+\sum_{i=1}^{3} a_{i} \cdot e^{-t / \tau_{i}}$, where $a_{0}=0.217$, $a_{1}=0.259, a_{2}=0.338, a_{3}=0.186, \tau_{1}=172.9$ years, $\tau_{2}=18.51$ years, and $\tau_{3}=1.186$ years. This plot is expanded (Figure $4 \mathrm{~b}$ ) to show the behaviour for short time horizons. The resulting profiles are different in all cases depending on the RE values and on the absolute and relative rate constants for reaction with $\mathrm{OH}$. For HFE-7200 $\left(\mathrm{C}_{4} \mathrm{~F}_{9} \mathrm{OC}_{2} \mathrm{H}_{5}\right)$, the net-GWP and direct-GWP are similar, showing that the indirect contribution due to products is small but non negligible. $\mathrm{C}_{4} \mathrm{~F}_{9} \mathrm{OC}(\mathrm{O}) \mathrm{CH}_{3}$ is the main oxidation product of HFE-7200 $(\alpha=0.8)$ but it has a short lifetime $(0.06$ yrs $)$ and thus a very low contribution to the net-GWP. On the other hand, $\mathrm{C}_{4} \mathrm{~F}_{9} \mathrm{OC}(\mathrm{O}) \mathrm{H}$ is also found as a product $(\tau=3 \mathrm{yrs}$ and $\left.\mathrm{RE}=0.59 \mathrm{~W} \mathrm{~m}^{-2} \mathrm{ppbv}^{-1}\right)$. Nevertheless, the yield of this compound is small, $\alpha=0.2$, and so its contribution to the net GWP is also low.

The oxidation of HFE-7000 leads to $\mathrm{C}_{3} \mathrm{~F}_{7} \mathrm{OC}(\mathrm{O}) \mathrm{H}$ as the only product. The lifetime of $\mathrm{C}_{3} \mathrm{~F}_{7} \mathrm{OC}(\mathrm{O}) \mathrm{H}$ (2.6 yrs) is on the same order as the lifetime of HFE-7000 (4.8 yrs) whereas its RE $\left(0.55 \mathrm{~W} \mathrm{~m}^{-2} \mathrm{ppbv}^{-}\right.$ $\left.{ }^{1}\right)$ is $70 \%$ larger than the HFE-7000 $\left(0.32 \mathrm{~W} \mathrm{~m}^{-2} \mathrm{ppbv}^{-1}\right)$. Consequently, the net-GWP is significantly higher than the direct-GWP for time horizons up to one hundred years.

Finally, $\left(\mathrm{CF}_{3}\right)_{2} \mathrm{CHOCH}_{3}$ leads to $\left(\mathrm{CF}_{3}\right)_{2} \mathrm{CHOC}(\mathrm{O}) \mathrm{H}$ as the major oxidation product, which has a lifetime 12 times longer (3.2 vs. $0.27 \mathrm{yrs})$ and an RE twice as large $\left(0.35\right.$ vs. $\left.0.19 \mathrm{~W} \mathrm{~m}^{-2} \mathrm{ppbv}^{-1}\right)$ than the parent HFE. At times longer than 0.25 years, the concentration of $\left(\mathrm{CF}_{3}\right)_{2} \mathrm{CHOC}(\mathrm{O}) \mathrm{H}$ exceeds that of the parent compound, $\left(\mathrm{CF}_{3}\right)_{2} \mathrm{CHOCH}_{3}$. The combination of both effects makes the net-GWP for this HFE extremely large compared to the direct-GWP for hundreds of years.

Table 4 summarizes the net-GWPs of some common HFEs whose atmospheric chemistry has been reported in the literature. For segregated FESs only one oxidation pathway is possible and the yields of the corresponding fluoroalkylformate are close to the unity. However, as was commented above, $\mathrm{C}_{4} \mathrm{~F}_{9} \mathrm{OC}_{2} \mathrm{H}_{5}$ (HFE-7200) has two different $\mathrm{H}$ atoms leading to the fluoroalkylacetate $\mathrm{C}_{4} \mathrm{~F}_{9} \mathrm{OC}(\mathrm{O}) \mathrm{CH}_{3}$ and the corresponding fluoroalkylformate $\mathrm{C}_{4} \mathrm{~F}_{9} \mathrm{OC}(\mathrm{O}) \mathrm{H}$ as major and minor oxidation products. On the other hand, non segregated FESs will lead to different species in their atmospheric oxidation depending on the strength of the $\mathrm{C}-\mathrm{H}$ bond of the abstracted $\mathrm{H}$ atom. ${ }^{[10]}$ On reaction with $\mathrm{OH}$, some HFEs can undergo decomposition via $\mathrm{C}-\mathrm{C}$ bond scission and release of $\mathrm{CF}_{3}$ radicals, which can then produce $\mathrm{COF}_{2} \cdot{ }^{[32]}$ This species can be rapidly removed by wet deposition, as described earlier, and we have not taken this compound into account in the net-GWP calculation. 
In general, the net-GWPs values obtained are between 2-16 times larger than the direct-GWPs for the studied HFEs at 20, 100 and 500 yrs. For segregated HFEs the contribution of the indirect-GWP is very significant. For instance, net-GWP ${ }_{100}$ values of 1320 and 1200 where found for $\mathrm{C}_{2} \mathrm{~F}_{5} \mathrm{OCH}_{3}$.and $\mathrm{CF}_{3} \mathrm{OCH}_{3}$, respectively, in contrast with their corresponding direct-GWP${ }_{100}, 573$ and 453, respectively. These values are comparable with those of some well-known greenhouse gases such as hydrofluorocarbons (HFCs). For example, $\mathrm{GWP}_{100}$ values of 1430 and 4470 where reported in the literature for $\mathrm{CH}_{2} \mathrm{FCF}_{3}$ and $\mathrm{CF}_{3} \mathrm{CH}_{3}$, respectively. ${ }^{[27]}$ For the non-segregated HFEs, net-GWP ${ }_{100}$ values are greater than the direct-GWP $\mathrm{GW0}_{100}$ values by more than a factor of ten, as is illustrated for $\left(\mathrm{CF}_{3}\right)_{2} \mathrm{CHOCH}_{3}\left(288\right.$ vs. 18) and $\mathrm{CF}_{3} \mathrm{CH}_{2} \mathrm{OCH}_{3}$ (63 vs. 6). On the other hand, for $\mathrm{CF}_{3} \mathrm{CHClOCHF}_{2}$ the net-GWP ${ }_{100}$ is only $35 \%$ larger than the direct-GWP G00 $_{1077}$ vs. 429) since the lifetime of the only oxidation product is very short.

On the basis of these results, some segregated HFEs may contribute significantly more to global warming than can be concluded from examination of their direct GWPs, and the applicability of some HFEs as environmentally-compatible CFCs, HFCs and PFC alternatives should be re-examined. As shown, in the design and development of CFC substitutes, the consideration of the contribution of atmospheric reaction products is a crucial factor to properly asses the impact on the global warming.

\section{Conclusion}

We have used density functional theory and the methodology developed in Bravo et al. (2010) ${ }^{[22]}$, to predict infrared spectra, and calculate REs and GWPs for a number of FESs for the first time. FESs are the major oxidation products of HFEs. Some of them such as fluoroalkylacetates, alkylfluoroacetates and fluoroalkylformates remain in the atmosphere for long periods until removed by oxidation by $\mathrm{OH}$ radicals and are potential greenhouse gases. The concept of indirect Global Warming Potential was used here to assess the climate impact of secondary stable species in the troposphere. Using this approach we found that the GWPs of HFEs can be increased within 100-1600\% taking into account the cumulative effect due to the secondary FESs formed during HFE atmospheric oxidation. This effect may be particularly significant for non segregated HFEs. Studies of the atmospheric chemistry of FESs such as gas-to-water equilibrium and solubility, atmospheric lifetimes, infrared spectra and reaction yields are needed to accurately assess the environmental impact of FESs and HFEs.

\section{Acknowledgments}

This work was supported by the Spanish Ministerio de Ciencia e Innovación (project CGL200762479/CLI) and Junta de Comunidades de Castilla La Mancha (Project PEII09-0262-2753). 


\section{Supplementary Information}

350 In the supplementary data associated with this article are the frequencies and absolute intensities of the vibrational modes of the studied FESs obtained using the B3LYP/6-31G** level of theory

352 7. References

353 [1] EPA, U.S. Environmental Protection Agency. Clean Air Act.

354 http://www.epa.gov/ozone/snap/index.html

355

356

357

358

359

360

361

362

363

364

365

366

367

368

369

370

371

372

373

374

375

[2] $3 \mathrm{M}^{\mathrm{TM}}$ Novec ${ }^{\mathrm{TM}}$ Engineered Fluids. http://www.3M.com

[3] Shine, K.P. Climate effect of inhaled anaesthetics. British Journal of anaesthesia 105 (6), 731-3, 2010.

[4] Sihra, K., Hurley, M. D., Shine, K. P. \& Wallington, T. J. Updated radiative forcing estimates of 65 halocarbons and nonmethane hydrocarbons. Journal of Geophysical Research 106, 20493-20505, 2001.

[5] Bravo, I,, Díaz-de-Mera, Y., Aranda, A., Smith, K, Shine, K. P., and Marston, G. Atmospheric chemistry of $\mathrm{C}_{4} \mathrm{~F}_{9} \mathrm{OC}_{2} \mathrm{H}_{5}$ (HFE-7200), $\mathrm{C}_{4} \mathrm{~F}_{9} \mathrm{OCH}_{3}$ (HFE-7100), $\mathrm{C}_{3} \mathrm{~F}_{7} \mathrm{OCH}_{3}$ (HFE-7000) and $\mathrm{C}_{3} \mathrm{~F}_{7} \mathrm{CH}_{2} \mathrm{OH}$ : temperature dependence of the kinetics of their reactions with $\mathrm{OH}$ radicals, atmospheric lifetimes and global warming potentials. Phys. Chem. Chem. Phys., 2010, 12, 5115-5125.

[6] Wallington, T.J., Schneider, W. F., Sehested, J., Bilde, M., Platz, J., Nielsen, O. J., Christensen, L. K., Molina, M. J., Molina, L. T., Wooldridge, P. W. Atmospheric Chemistry of HFE-7100 (C4F9OCH3): Reaction with OH Radicals, UV Spectra and Kinetic Data for C4F9OCH2 and C4F9OCH2O2. Radicals, and the Atmospheric Fate of C4F9OCH2O. Radicals. Journal Of Physical Chemistry A, 101, 8264, 1997.

[7] Christensen, L. K. Sehested, J., Nielsen, O. J., Bilde, M., Wallington, T. J., Guschin, A., Molina, L. T., Molina, M. J. Atmospheric Chemistry of HFE-7200 $\left(\mathrm{C}_{4} \mathrm{~F}_{9} \mathrm{OC}_{2} \mathrm{H}_{5}\right)$ : Reaction with OH Radicals and Fate of $\mathrm{C}_{4} \mathrm{~F}_{9} \mathrm{OCH}_{2} \mathrm{CH}_{2} \mathrm{O}$ and $\mathrm{C}_{4} \mathrm{~F}_{9} \mathrm{OCHOCH}_{3}$ Radicals. Journal of Physical Chemistry A 1998, 102, 4839.

[8] Christensen, L. K., Wallington, T. J., Guschin, A., Hurley, M. D. Atmospheric Degradation Mechanism of $\mathrm{CF}_{3} \mathrm{OCH}_{3}$. Journal of Physical Chemistry A, 1999, 103, 4202-4208. 
[9] Ninomiya, Y., Kawasaki, M. Guschin, A., Molina, L. T., Molina, M. J., Wallington, T. J. Atmospheric Chemistry of $\mathrm{n}-\mathrm{C}_{3} \mathrm{~F}_{7} \mathrm{OCH}_{3}$ : Reaction with $\mathrm{OH}$ Radicals and $\mathrm{Cl}$ Atoms and Atmospheric Fate of $\mathrm{n}_{-} \mathrm{C}_{3} \mathrm{~F}_{7} \mathrm{OCH}_{2} \mathrm{O}(\bullet)$ Radicals. Environmental Science \& Technology, 34, 2973, 2000.

[10] Oyaro, N., Sellevag, S.R., Nielsen, C.J. Study of the OH and Cl-Initiated Oxidation, IR Absorption Cross-Section, Radiative Forcing, and Global Warming Potential of Four C4Hydrofluoroethers. Environmental Science \& Technology. 38, 5567-5576, 2004.

[11] Chen,. L., Kutsuna, S., Tokuhashi, K. and Sekiya, A. Kinetic study of the gas-phase reactions of $\mathrm{C}_{2} \mathrm{~F}_{5} \mathrm{OC}(\mathrm{O}) \mathrm{H}$ and $n-\mathrm{C}_{3} \mathrm{~F}_{7} \mathrm{OC}(\mathrm{O}) \mathrm{H}$ with $\mathrm{OH}$ radicals at 253-328 K. Chem. Phys. Letter. 400, 563-568, 2004.

[12] Chen,. L., Kutsuna, S., Tokuhashi, K. and Sekiya, A. Kinetic of the gas phase Reaction of $\mathrm{CF}_{3} \mathrm{OC}(\mathrm{O}) \mathrm{H}$ with $\mathrm{OH}$ Radicals at 242-328 K. International Journal of Chemical Kinetics. 36, 6, $337-$ $344,2004$.

[13] Chen,. L., Kutsuna, S., Tokuhashi, K. and Sekiya, A. Kinetic and Mechanisms of $\mathrm{CF}_{3} \mathrm{CHFOCH}_{3}$, $\mathrm{CF}_{3} \mathrm{CHFOC}(\mathrm{O}) \mathrm{H}$, and $\mathrm{FC}(\mathrm{O}) \mathrm{OCH}_{3}$ Reactions with $\mathrm{OH}$ Radicals. J. Phys. Chem. A. 110, $12845-$ $12851,2006$.

[14] Blanco M.B., Teruel M.A. Atmospheric degradation of fluoroesters (FESs): Gas-phase reactivity study towards OH radicals at 298 K. Atmospheric Environment 41, 7330-7338, 2007.

[15] Blanco M.B., Bejan I., Barnes I., Wiesen P., Teruel M.A. Kinetic of the reactions of chlorine atoms with selected fluoroacetates at atmospheric pressure and 298 K. Chem. Phys. Letter. 453, 18-23, 2008.

[15] Hudlicky, M., Chemistry of Organic Fluorine Compounds, 2nd Edition. Ellis Horwood, Chichester, pp. 255-257, 1976

[16] Kutsuna, S., Chen, L., Ohno, K., Tokuhashi, K., Sekiya, A. Henry’s law constants and hydrolysis rate constants of 2,2,2-trifluoroethyl acetate and methyl trifluoroacetate. Atmospheric Environment 38, 725-732, 2004.

[17] Chen,. L., Kutsuna, S., Tokuhashi, K. and Sekiya, A., Tamai, R., Hibino, Y. Kinetics and Mechanism of $\left(\mathrm{CF}_{3}\right)_{2} \mathrm{CHOCH}_{3}$ Reaction with $\mathrm{OH}$ Radicals in an Environmental Reaction Chamber. $J$. Phys. Chem. A, 109, 4766-4771, 2005.

[18] Wallington, T. J., Hurley, M. D., Fedotov, V., Morrell, C. and Hancock, G. Atmospheric Chemistry of $\mathrm{CF}_{3} \mathrm{CH}_{2} \mathrm{OCHF}_{2}$ and $\mathrm{CF}_{3} \mathrm{CHClOCHF}_{2}$ : Kinetics and Mechanisms of Reaction with $\mathrm{Cl}$ 
Atoms and $\mathrm{OH}$ Radicals and Atmospheric Fate of $\mathrm{CF}_{3} \mathrm{C}(\mathrm{O}) \mathrm{HOCHF}_{2}$ and $\mathrm{CF}_{3} \mathrm{C}(\mathrm{O}) \mathrm{ClOCHF}_{2}$ Radicals. J. Phys. Chem. A 106, 8391-8398, 2002.

[19] Mellouki, A., Le Bras, G., Sidebottom, H. Kinetics and mechanisms of the oxidation of oxygenated organic compounds in the gas phase. Chemical Review 103, 5077-5096, 2003.

[20] Nohara, K., Toma, M., Kutsuna, S., Takeuchi, K., and Ibusuki, T. Cl Atom-Initiated Oxidation of Three Homologous Methyl Perfluoroalkyl Ethers. Environ. Sci. Technol., 35 (1), pp 114-120, 2001.

[21] Bravo., I., Marston, G., Nutt, D. R., Shine, K.P. Radiative efficiencies and global warming potentials using theoretically-determined absorption cross-sections for several hydrofluoroethers (HFEs) and hydrofluoropolyethers (HFPEs). JQSRT, 2011, doi:10.1016/j.jqsrt.2011.05.001

[22] Bravo, I., A. Aranda, M. D. Hurley, G. Marston, D. R. Nutt, K. P. Shine, K. Smith, and T. J. Wallington (2010), Infrared absorption spectra, radiative efficiencies, and global warming potentials of perfluorocarbons: Comparison between experiment and theory, J. Geophys. Res., 115, D24317, 2010.

[23] Pinnock, S., Hurley, M. D., Shine, K. P., Wallington, T. J. and Smyth, T. J., 'Radiative forcing of climate by hydrochlorofluorocarbons and hydrofluorocarbons. J. Geophys. Res. 100, 23227-23238, 1995.

[24] J. Frisch, H. B. Schlegel, G. E. Scuseria, M. A. Robb, J. R. Cheeseman, J. A. Montgomery, Jr., T. Vreven, K. N. Kudin, J. C. Burant, J. M. Millam, S. S. Iyengar, J. Tomasi, V. Barone, B. Mennucci, M. Cossi, G. Scalmani, N. Rega, G. A. Petersson, H. Nakatsuji, M. Hada, M. Ehara, K. Toyota, R. Fukuda, J. Hasegawa, M. Ishida, T. Nakajima, Y. Honda, O. Kitao, H. Nakai, M. Klene, X. Li, J. E. Knox, H. P. Hratchian, J. B. Cross, V. Bakken, C. Adamo, J. Jaramillo, R. Gomperts, R. E. Stratmann, O. Yazyev, A. J. Austin, R. Cammi, C. Pomelli, J. W. Ochterski, P. Y. Ayala, K. Morokuma, G. A. Voth, P. Salvador, J. J. Dannenberg, V. G. Zakrzewski, S. Dapprich, A. D. Daniels, M. C. Strain, O. Farkas, D. K. Malick, A. D. Rabuck, K. Raghavachari, J. B. Foresman, J. V. Ortiz, Q. Cui, A. G. Baboul, S. Clifford, J. Cioslowski, B. B. Stefanov, G. Liu, A. Liashenko, P. Piskorz, I. Komaromi, R. L. Martin, D. J. Fox, T. Keith, M. A. Al-Laham, C. Y. Peng, A. Nanayakkara, M. Challacombe, P. M. W. Gill, B. Johnson, W. Chen, M. W. Wong, C. Gonzalez, and J. A. Pople. Gaussian 03, Revision C.02; Gaussian, Inc: Wallingford CT, 2004.

[25] Blowers, P., Moline, D. M., Tetrault, K. F., Wheeler, R. R. and Tuchawena, S.L., 'Prediction of radiative forcing values for hydrofluoroethers using density functional theory methods', J. Geophys. Res., 112, D15108, 2007. 
[26] Papasavva, S., S. Tai, K. H. Illinger, and J. E. Kenny, Infrared radiative forcing of CFC substitutes and their atmospheric reaction products, J. Geophys. Res., 102, 13,643-13,650, 1997.

[27] Forster, P. M. D., Ramaswamy, V., Artaxo, P., Berntsen, T., Betts, R., Fahey, D. W., Haywood, J., Lean, J. Lowe, D. C. Myhre, G. Nganga, J. Prinn, R. Raga, G. Schulz, M. Van Dorland, R. in Fourth Assessment Report of the Intergovernmental Panel on Climate Change (Ed.: S. Solomon), Cambridge, 2007.

[28] Stein, T. N. N. Christensen, L. K. Platz, J. Sehested, J. Nielsen, O. J. Wallington. T.J. Atmospheric Chemistry of $\mathrm{CF}_{3} \mathrm{C}(\mathrm{O}) \mathrm{OCH}_{2} \mathrm{CF}_{3}$ : UV Spectra and Kinetic Data for $\mathrm{CF}_{3} \mathrm{C}(\mathrm{O}) \mathrm{OCHCF}_{3}$ and $\mathrm{CF}_{3} \mathrm{C}(\mathrm{O}) \mathrm{OCH}(\mathrm{OO}) \mathrm{CF}_{3}$ Radicals, and Atmospheric Fate of $\mathrm{CF}_{3} \mathrm{C}(\mathrm{O}) \mathrm{OCH}(\mathrm{O}) \mathrm{CF}_{3}$ Radicals. $J$. Phys. Chem. A 103, 5705-5713, 1999.

[29] Young, C. J., Hurley, M. D. Wallington, T. J. and Mabury, S. A. Molecular structure and radiative efficiency of fluorinated ethers: A structure-activity relationship, J. Geophys. Res., 113, D24301, 2008.

[30] Chen, L. Kutsuna, S., Nohara, K., Takeuchi, K. and Ibusuki, T. Kinetics and Mechanisms for the Reactions of $\mathrm{CF}_{3} \mathrm{OCH}_{3}$ and $\mathrm{CF}_{3} \mathrm{OC}(\mathrm{O}) \mathrm{H}$ with $\mathrm{OH}$ Radicals Using an Environmental Reaction Chamber. J. Phys. Chem. A 105, 10854-10859, 2001.

[31] De Bruyn, W. J., Shorter J. A., Davidovits P., Worsnop D. R., Zahniser M. S., Kolb C. E. Uptake of Haloacetyl and Carbonyl Halides by Water Surfaces. Environ. Sci. Technol., 29, 1179-1185, 1995.

[32] Wallington, T.J., Guschin, A.; Stein, T. N. N.; Platz, J.; Sehested, J.; Christensen, L. K.; Nielsen, O. J., Atmospheric chemistry of $\mathrm{CF}_{3} \mathrm{CH}_{2} \mathrm{OCH}_{2} \mathrm{CF}_{3}$ : UV spectra and kinetic data for $\mathrm{CF}_{3} \mathrm{CH}(.) \mathrm{OCH}_{2} \mathrm{CF}_{3}$ and $\mathrm{CF}_{3} \mathrm{CH}(\mathrm{OO}().) \mathrm{OCH}_{2} \mathrm{CF}_{3}$ radicals and atmospheric fate of $\mathrm{CF}_{3} \mathrm{CH}(\mathrm{O}().) \mathrm{OCH}_{2} \mathrm{CF}_{3}$ radicals. J. Phys. Chem. A, 102: p. 1152-1161, 1998.

[33] Atkinson, R., Kinetic and mechanisms of the gas-phase reactions of hydroxyl radical with organic compounds under atmospheric conditions. Chemical Reviews 86 (1)m 69-201, 1986.

[34] Oyaro, N., Sellevag, S. R., Nielsen, C. J. Atmospheric Chemistry of Hydrofluoroethers: Reaction of a Series of Hydrofluoroethers with $\mathrm{OH}$ Radicals and $\mathrm{Cl}$ Atoms, Atmospheric Lifetimes, and Global Warming Potentials. J. Phys Chem. A 109, 337, 2005.

[35] Goto, M., Kawasaki, M., Wallington, T.J., Hurley, M.D., Sharratt, A.P. Atmospheric Chemistry of $\mathrm{CH}_{2} \mathrm{FOCH}_{2} \mathrm{~F}$ : Reaction with $\mathrm{Cl}$ Atoms and Atmospheric Fate of $\mathrm{CH}_{2} \mathrm{FOCHFO}$ Radicals. International Journal of Chemical Kinetics 34, 3, 139-147, 2002. 
467 [36] Tsai, W.T. Environmental risk assessment of hydrofluoroethers (HFEs), J. Hazardous Materials 468 A119, 69-78, 2005.

469 [37] Myhre, G. Nielsen, C.J. Powell, D.L. and Stordal, F. Infrared absorption cross section, radiative 470 forcing, and GWP of four hydrofluoro(poly)ethers, Atmos. Environ. 33 (1999), pp. 4447-4458.

471 [38] Good, D.A., Kamboures, M., Santiano, R., and Francisco, J.S. Atmospheric Oxidation of 472 Fluorinated Ethers, E143a $\left(\mathrm{CF}_{3} \mathrm{OCH}_{3}\right), \mathrm{E} 134\left(\mathrm{CHF}_{2} \mathrm{OCHF}_{2}\right)$, and E125 $\left(\mathrm{CHF}_{2} \mathrm{OCF}_{3}\right)$. J. Phys. Chem. A $473103,9230-9240,1999$.

474 [39] Orkin, V.L., Villenave, E., Huie, R.E., and Kurylo, M.J. Atmospheric Lifetimes and Global 475 Warming Potentials of Hydrofluoroethers: Reactivity toward OH, UV Spectra, and IR Absorption 476 Cross Sections. J. Phys. Chem. A, 103, 9770-9779, 1999.

477 [40] Sulbaek-Andersen MP, Sander SP, Nielsen OJ, Wagner DS, Sanford TJ Jr, Wallington TJ. 478 Inhalation anaesthetics and climate change. Br J Anaesth; 105: 760-766, 2010.

479 [41] Tokuhashi, K., Nagai, H., Takahashi, A., Kaise, M., Kondo, S., Sekiya, A., Takahashi, M., Gotoh, 480 Y., Suga, A. Rate constants for the reactions of $\mathrm{OH}$ radicals with $\mathrm{CH}_{3} \mathrm{OCF}_{2} \mathrm{CF}_{3}, \mathrm{CH}_{3} \mathrm{OCF}_{2} \mathrm{CF}_{2} \mathrm{CF}_{3}$, and $481 \quad \mathrm{CH}_{3} \mathrm{OCF}\left(\mathrm{CF}_{3}\right)_{2}$. Int. J. Chem. Kinetic 1999; 31(12): 846-853. 
Tables and Figures

Table 1. Theoretically-determined integrated cross sections (between 0 and $2500 \mathrm{~cm}^{-1}$ ) in $10^{-17} \mathrm{~cm}^{2} \mathrm{molecule}^{-1} \mathrm{~cm}^{-1}$ )

\begin{tabular}{|c|c|c|c|c|c|}
\hline & FESs & $\mathrm{S} / 10^{-17} \mathrm{~cm}^{2}$ molecule ${ }^{-1}$ & & FESs & $\mathrm{S} / 10^{-17} \mathrm{~cm}^{2}$ molecule ${ }^{-1}$ \\
\hline \multirow{8}{*}{ 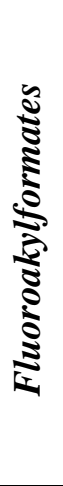 } & $\mathrm{CF}_{3} \mathrm{OC}(\mathrm{O}) \mathrm{H}$ & 30.9 & \multirow{14}{*}{ 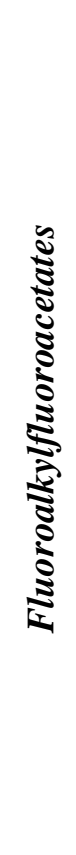 } & $\mathrm{CF}_{3} \mathrm{C}(\mathrm{O}) \mathrm{OCH}_{3}$ & 23.2 \\
\hline & $\mathrm{C}_{2} \mathrm{~F}_{5} \mathrm{OC}(\mathrm{O}) \mathrm{H}$ & 35.6 & & $\mathrm{CF}_{3} \mathrm{C}(\mathrm{O}) \mathrm{OCF}_{3}$ & 43.2 \\
\hline & $\mathrm{C}_{3} \mathrm{~F}_{7} \mathrm{OC}(\mathrm{O}) \mathrm{H}$ & 41.2 & & $\mathrm{CF}_{3} \mathrm{C}(\mathrm{O}) \mathrm{OCH}_{2} \mathrm{CH}_{3}$ & 25.5 \\
\hline & $\mathrm{C}_{4} \mathrm{~F}_{9} \mathrm{OC}(\mathrm{O}) \mathrm{H}$ & 46.6 & & $\mathrm{CF}_{3} \mathrm{C}(\mathrm{O}) \mathrm{OCH}_{2} \mathrm{CF}_{3}$ & 37.0 \\
\hline & $\mathrm{CF}_{3} \mathrm{CHFOC}(\mathrm{O}) \mathrm{H}$ & 29.2 & & $\mathrm{CF}_{3} \mathrm{C}(\mathrm{O}) \mathrm{OCF}_{2} \mathrm{CF}_{3}$ & 47.5 \\
\hline & $\left(\mathrm{CF}_{3}\right)_{2} \mathrm{CHOC}(\mathrm{O}) \mathrm{H}$ & 36.5 & & $\mathrm{CF}_{3} \mathrm{C}(\mathrm{O}) \mathrm{OCF}_{2} \mathrm{CH}_{3}$ & 38.0 \\
\hline & $\mathrm{CF}_{3} \mathrm{CH}_{2} \mathrm{OC}(\mathrm{O}) \mathrm{H}$ & 25.0 & & $\mathrm{CF}_{3} \mathrm{C}(\mathrm{O}) \mathrm{OCH}=\mathrm{CH}_{2}$ & 27.6 \\
\hline & $\mathrm{CF}_{3} \mathrm{CH}_{2} \mathrm{CH}_{2} \mathrm{OC}(\mathrm{O}) \mathrm{H}$ & 26.1 & & $\mathrm{CF}_{3} \mathrm{C}(\mathrm{O}) \mathrm{OCH}_{2} \mathrm{CH}=\mathrm{CH}_{2}$ & 28.0 \\
\hline \multirow{6}{*}{ 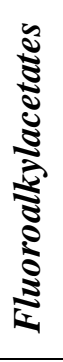 } & & & & $\mathrm{CF}_{3} \mathrm{C}(\mathrm{O}) \mathrm{OCH}\left(\mathrm{CF}_{3}\right)_{2}$ & 48.5 \\
\hline & $\mathrm{CH}_{3} \mathrm{C}(\mathrm{O}) \mathrm{OCF}_{3}$ & 34.0 & & $\mathrm{CF}_{3} \mathrm{C}(\mathrm{O}) \mathrm{OPh}$ & 31.9 \\
\hline & $\mathrm{CH}_{3} \mathrm{C}(\mathrm{O}) \mathrm{OC}_{2} \mathrm{~F}_{5}$ & 38.6 & & $\mathrm{CF}_{3} \mathrm{C}(\mathrm{O}) \mathrm{OCHF}_{2}$ & 36.1 \\
\hline & $\mathrm{CH}_{3} \mathrm{C}(\mathrm{O}) \mathrm{OC}_{3} \mathrm{~F}_{7}$ & 44.4 & & $\mathrm{HCF}_{2} \mathrm{C}(\mathrm{O}) \mathrm{OCH}_{3}$ & 17.2 \\
\hline & $\mathrm{CH}_{3} \mathrm{C}(\mathrm{O}) \mathrm{OC}_{4} \mathrm{~F}_{9}$ & 49.8 & & $\mathrm{H}_{2} \mathrm{CFC}(\mathrm{O}) \mathrm{OCH}_{3}$ & 14.0 \\
\hline & & & & $\mathrm{HCF}_{2} \mathrm{C}(\mathrm{O}) \mathrm{OCH}_{3}$ & 30.2 \\
\hline \multirow{8}{*}{ 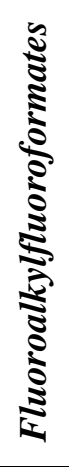 } & $\mathrm{FC}(\mathrm{O}) \mathrm{OCH}_{3}$ & 18.4 & & & \\
\hline & $\mathrm{FC}(\mathrm{O}) \mathrm{OCH}_{2} \mathrm{~F}$ & 23.5 & & & \\
\hline & $\mathrm{FC}(\mathrm{O}) \mathrm{OCF}_{2} \mathrm{H}$ & 30.5 & & & \\
\hline & $\mathrm{FC}(\mathrm{O}) \mathrm{OCF}_{3}$ & 37.1 & & & \\
\hline & $\mathrm{FC}(\mathrm{O}) \mathrm{OC}_{2} \mathrm{~F}_{5}$ & 41.7 & & & \\
\hline & $\mathrm{FC}(\mathrm{O}) \mathrm{OCH} 2 \mathrm{CF}_{3}$ & 30.0 & & & \\
\hline & $\mathrm{FC}(\mathrm{O}) \mathrm{OCF} 2 \mathrm{CH}_{3}$ & 32.2 & & & \\
\hline & $\mathrm{FC}(\mathrm{O}) \mathrm{C}_{3} \mathrm{~F}_{7}$ & 47.4 & & & \\
\hline
\end{tabular}


Table 2. Radiative efficiencies (in $\mathrm{W} \mathrm{m}^{-2} \mathrm{ppbv}^{-1}$ ) calculated using theoretically-determined absorption crosssections (Table 1), with wavenumber correction applied for selected fluorinated esters. These are compared with literature values for the parent HFEs where available. The REs assume that the compound is well-mixed in the atmosphere

\begin{tabular}{|c|c|c|c|c|c|}
\hline FESs & RE (This work) & \multicolumn{2}{|c|}{ Parent HFE / Reference } & \multicolumn{2}{|c|}{ RE / Reference } \\
\hline $\mathrm{CF}_{3} \mathrm{OC}(\mathrm{O}) \mathrm{H}$ & 0.32 & $\mathrm{CF}_{3} \mathrm{OCH}_{3}(\mathrm{HFE}-143 \mathrm{a})$ & {$[30][8][12]$} & 0.19 & {$[21]$} \\
\hline $\mathrm{C}_{2} \mathrm{~F}_{5} \mathrm{OC}(\mathrm{O}) \mathrm{H}$ & 0.48 & $\mathrm{CH}_{3} \mathrm{OCF}_{2} \mathrm{CF}_{3}$ & {$[20][11]$} & 0.36 & {$[21]$} \\
\hline $\mathrm{C}_{3} \mathrm{~F}_{7} \mathrm{OC}(\mathrm{O}) \mathrm{H}$ & 0.55 & $\mathrm{CH}_{3} \mathrm{OCF}_{2} \mathrm{CF}_{2} \mathrm{CF}_{3}(\mathrm{HFE}-7000)$ & {$[20][11][9]$} & 0.37 & [5] \\
\hline $\mathrm{C}_{4} \mathrm{~F}_{9} \mathrm{OC}(\mathrm{O}) \mathrm{H}$ & 0.59 & $\begin{array}{c}\mathrm{CH}_{3} \mathrm{OC}_{4} \mathrm{~F}_{9}(\mathrm{HFE}-7100) ; \\
\mathrm{CH}_{3} \mathrm{CH}_{2} \mathrm{OC}_{4} \mathrm{~F}_{9}(\mathrm{HFE}-7200)\end{array}$ & $\begin{array}{l}{[6]} \\
{[7]}\end{array}$ & $\begin{array}{l}0.36 \\
0.42\end{array}$ & {$[5]$} \\
\hline $\mathrm{CF}_{3} \mathrm{CHFOC}(\mathrm{O}) \mathrm{H}$ & 0.38 & $\mathrm{CF}_{3} \mathrm{CHFOCH}_{3}$ & [13] & 0.29 & {$[25]$} \\
\hline$\left(\mathrm{CF}_{3}\right)_{2} \mathrm{CHOC}(\mathrm{O}) \mathrm{H}$ & 0.35 & $\left(\mathrm{CF}_{3}\right)_{2} \mathrm{CHOCH}_{3}$ & [17] & 0.31 & {$[10]$} \\
\hline $\mathrm{CF}_{3} \mathrm{CH}_{2} \mathrm{OC}(\mathrm{O}) \mathrm{H}$ & 0.26 & $\begin{array}{c}\mathrm{CF}_{3} \mathrm{CH}_{2} \mathrm{OCH}_{2} \mathrm{CF}_{3} \text { (HFE-356mff) } \\
\mathrm{CH}_{3} \mathrm{OCH}_{2} \mathrm{CF}_{3}\end{array}$ & $\begin{array}{c}{[10][32]} \\
{[34]}\end{array}$ & $\begin{array}{l}0.33 \\
0.19\end{array}$ & $\begin{array}{l}{[10]} \\
{[34]}\end{array}$ \\
\hline $\mathrm{CF}_{3} \mathrm{CH}_{2} \mathrm{CH}_{2} \mathrm{OC}(\mathrm{O}) \mathrm{H}$ & 0.26 & NA & NA & NA & NA \\
\hline $\mathrm{CH}_{3} \mathrm{C}(\mathrm{O}) \mathrm{OCF}_{3}$ & 0.38 & $\mathrm{CH}_{3} \mathrm{CH}_{2} \mathrm{OCF}_{3}$ & [34] & 0.21 & {$[34]$} \\
\hline $\mathrm{CH}_{3 \mathrm{C}}(\mathrm{O}) \mathrm{OC}_{2} \mathrm{~F}_{5}$ & 0.55 & NA & NA & NA & NA \\
\hline $\mathrm{CH}_{3} \mathrm{C}(\mathrm{O}) \mathrm{OC}_{3} \mathrm{~F}_{7}$ & 0.54 & NA & NA & NA & NA \\
\hline $\mathrm{CH}_{3} \mathrm{C}(\mathrm{O}) \mathrm{OC}_{4} \mathrm{~F}_{9}$ & 0.66 & $\mathrm{C}_{2} \mathrm{H}_{5} \mathrm{OC}_{4} \mathrm{~F}_{9}(\mathrm{HFE}-7200)$ & [7] & 0.42 & {$[5]$} \\
\hline $\mathrm{CH}_{3} \mathrm{OC}(\mathrm{O}) \mathrm{F}$ & 0.08 & $\mathrm{CF}_{3} \mathrm{CHFOCH}_{3}$ & [13] & 0.29 & {$[25]$} \\
\hline $\mathrm{H}_{2} \mathrm{FCOC}(\mathrm{O}) \mathrm{F}$ & 0.18 & $\mathrm{CH}_{2} \mathrm{FOCH}_{2} \mathrm{~F}$ & [35] & N/A & \\
\hline $\mathrm{HF}_{2} \mathrm{COC}(\mathrm{O}) \mathrm{F}$ & 0.32 & $\begin{array}{c}\mathrm{HF}_{2} \mathrm{COCF}_{2} \mathrm{H}(\mathrm{HFE}-134) \\
\mathrm{CF}_{3} \mathrm{CHFOCHF}_{2}\end{array}$ & $\begin{array}{l}{[36]} \\
{[34]}\end{array}$ & $\begin{array}{l}0.40 \\
0.45\end{array}$ & $\begin{array}{l}{[37]} \\
{[34]}\end{array}$ \\
\hline $\mathrm{CF}_{3} \mathrm{OC}(\mathrm{O}) \mathrm{F}$ & 0.31 & $\begin{array}{c}\mathrm{CF}_{3} \mathrm{OCFHCF}_{3}(\mathrm{HFE}-227 \mathrm{me}) \\
\mathrm{CF}_{3} \mathrm{OCF}_{2} \mathrm{H}(\mathrm{HFE}-125)\end{array}$ & $\begin{array}{c}{[38]} \\
{[39][36]}\end{array}$ & $\begin{array}{l}0.40 \\
0.41\end{array}$ & $\begin{array}{c}{[34]} \\
{[4]}\end{array}$ \\
\hline $\mathrm{C}_{2} \mathrm{~F}_{5} \mathrm{OC}(\mathrm{O}) \mathrm{F}$ & 0.46 & NA & NA & NA & NA \\
\hline $\mathrm{CF}_{3} \mathrm{CH}_{2} \mathrm{OC}(\mathrm{O}) \mathrm{F}$ & 0.31 & NA & NA & NA & NA \\
\hline $\mathrm{CH}_{3} \mathrm{CF}_{2} \mathrm{OC}(\mathrm{O}) \mathrm{F}$ & 0.34 & NA & NA & NA & NA \\
\hline $\mathrm{C}_{3} \mathrm{~F}_{7} \mathrm{OC}(\mathrm{O}) \mathrm{F}$ & 0.51 & NA & NA & NA & NA \\
\hline $\mathrm{CF}_{3} \mathrm{C}(\mathrm{O}) \mathrm{OCH}_{3}$ & 0.26 & $\left(\mathrm{CF}_{3}\right)_{2} \mathrm{CHOCH}_{3} / \mathrm{CH}_{3} \mathrm{OCH}_{2} \mathrm{CF}_{3}$ & {$[17][10][34]$} & $\begin{array}{l}0.31 \\
0.19\end{array}$ & $\begin{array}{l}10] \\
{[34]}\end{array}$ \\
\hline $\mathrm{CF}_{3} \mathrm{C}(\mathrm{O}) \mathrm{OCF}_{3}$ & 0.48 & NA & NA & $\mathrm{NA}$ & $\mathrm{NA}$ \\
\hline $\mathrm{CF}_{3} \mathrm{C}(\mathrm{O}) \mathrm{OCH}_{2} \mathrm{CH}_{3}$ & 0.29 & NA & NA & NA & $\mathrm{NA}$ \\
\hline $\mathrm{CF}_{3} \mathrm{C}(\mathrm{O}) \mathrm{OCH}_{2} \mathrm{CF}_{3}$ & 0.41 & $\mathrm{CF}_{3} \mathrm{CH}_{2} \mathrm{OCH}_{2} \mathrm{CF}_{3}$ & {$[10]$} & 0.33 & {$[10]$} \\
\hline $\mathrm{CF}_{3} \mathrm{C}(\mathrm{O}) \mathrm{OCF}_{2} \mathrm{CF}_{3}$ & 0.59 & NA & $\mathrm{NA}$ & $\mathrm{NA}$ & $\mathrm{NA}$ \\
\hline $\mathrm{CF}_{3} \mathrm{C}(\mathrm{O}) \mathrm{OCF}_{2} \mathrm{CH}_{3}$ & 0.51 & NA & NA & NA & $\mathrm{NA}$ \\
\hline $\mathrm{CF}_{3} \mathrm{C}(\mathrm{O}) \mathrm{OCH}=\mathrm{CH}_{2}$ & 0.37 & NA & NA & NA & NA \\
\hline $\mathrm{CF}_{3} \mathrm{C}(\mathrm{O}) \mathrm{OCH}_{2} \mathrm{CH}=\mathrm{CH}_{2}$ & 0.33 & NA & NA & $\mathrm{NA}$ & $\mathrm{NA}$ \\
\hline $\mathrm{CF}_{3} \mathrm{C}(\mathrm{O}) \mathrm{OCH}\left(\mathrm{CF}_{3}\right)_{2}$ & 0.47 & NA & NA & NA & NA \\
\hline $\mathrm{CF}_{3} \mathrm{C}(\mathrm{O}) \mathrm{OPh}$ & 0.37 & NA & NA & NA & NA \\
\hline $\mathrm{CF}_{3} \mathrm{C}(\mathrm{O}) \mathrm{OCHF}_{2}$ & 0.47 & $\begin{array}{l}\mathrm{CF}_{3} \mathrm{CHClOCHF}_{2} \\
\mathrm{CF}_{3} \mathrm{CH}_{2} \mathrm{OCHF}_{2}\end{array}$ & [18] & $\begin{array}{l}0.45 \\
0.37\end{array}$ & $\begin{array}{l}{[40]} \\
{[34]}\end{array}$ \\
\hline $\mathrm{HCF}_{2} \mathrm{C}(\mathrm{O}) \mathrm{OCH}_{3}$ & 0.08 & NA & NA & $\mathrm{NA}$ & $\mathrm{NA}$ \\
\hline $\mathrm{H}_{2} \mathrm{CFC}(\mathrm{O}) \mathrm{OCH}_{3}$ & 0.18 & NA & NA & $\mathrm{NA}$ & $\mathrm{NA}$ \\
\hline $\mathrm{HCF}_{2} \mathrm{C}(\mathrm{O}) \mathrm{OCH}_{3}$ & 0.41 & NA & NA & $\mathrm{NA}$ & $\mathrm{NA}$ \\
\hline
\end{tabular}


Table 3. Global warming potentials (GWP) at time horizons of 20, 100 and 500 years calculated using literature values of atmospheric lifetimes and theoretically-determined radiative efficiencies calculated here (Table 2) applying the lifetime-dependent correction of Sihra et al. $(2001)^{[4]}$ to crudely account for the departure of the vertical profile from well-mixed..

\begin{tabular}{|c|c|c|c|c|c|}
\hline \multirow{2}{*}{$\frac{\text { Compound }}{\mathrm{CF}_{3} \mathrm{OC}(\mathrm{O}) \mathrm{H}}$} & \multicolumn{2}{|c|}{ lifetimes (yr) / Reference } & \multirow{2}{*}{$\frac{\mathbf{G W P}_{\mathbf{2 0}}}{1970}$} & \multirow{2}{*}{$\frac{\mathbf{G W P}_{\mathbf{1 0 0}}}{561}$} & \multirow{2}{*}{$\frac{\text { GWP }_{\mathbf{5 0 0}}}{170}$} \\
\hline & 3.60 & {$[12]$} & & & \\
\hline $\mathrm{C}_{2} \mathrm{~F}_{5} \mathrm{OC}(\mathrm{O}) \mathrm{H}$ & 3.60 & {$[11]$} & 2020 & 575 & 174 \\
\hline $\mathrm{C}_{3} \mathrm{~F}_{7} \mathrm{OC}(\mathrm{O}) \mathrm{H}$ & 2.60 & {$[11]$} & 1270 & 361 & 109 \\
\hline $\mathrm{C}_{4} \mathrm{~F}_{9} \mathrm{OC}(\mathrm{O}) \mathrm{H}$ & 3.00 & {$[6]$} & 1270 & 362 & 110 \\
\hline $\mathrm{CF}_{3} \mathrm{CHFOC}(\mathrm{O}) \mathrm{H}$ & 3.20 & {$[13]$} & 1590 & 451 & 137 \\
\hline$\left(\mathrm{CF}_{3}\right)_{2} \mathrm{CHOC}(\mathrm{O}) \mathrm{H}$ & 3.20 & & 1090 & 310 & 94 \\
\hline $\mathrm{CF}_{3} \mathrm{CH}_{2} \mathrm{OC}(\mathrm{O}) \mathrm{H}$ & 0.44 & {$[10]$} & 140 & 40 & 12 \\
\hline $\mathrm{CF}_{3} \mathrm{CH}_{2} \mathrm{CH}_{2} \mathrm{OC}(\mathrm{O}) \mathrm{H}$ & 0.30 & & 79 & 22 & 7 \\
\hline $\mathrm{CH}_{3} \mathrm{C}(\mathrm{O}) \mathrm{OCF}_{3}$ & 0.06 & & 14 & 4 & 1 \\
\hline $\mathrm{CH}_{3 \mathrm{C}}(\mathrm{O}) \mathrm{OC}_{2} \mathrm{~F}_{5}$ & 0.06 & & 15 & 4 & 1 \\
\hline $\mathrm{CH}_{3} \mathrm{C}(\mathrm{O}) \mathrm{OC}_{3} \mathrm{~F}_{7}$ & 0.06 & & 11 & 3 & 1 \\
\hline $\mathrm{CH}_{3} \mathrm{C}(\mathrm{O}) \mathrm{OC}_{4} \mathrm{~F}_{9}$ & 0.06 & [7] & 11 & 3 & 1 \\
\hline $\mathrm{CH}_{3} \mathrm{OC}(\mathrm{O}) \mathrm{F}$ & 1.80 & [13] & 323 & 92 & 28 \\
\hline $\mathrm{H}_{2} \mathrm{FCOC}(\mathrm{O}) \mathrm{F}$ & NA & & & & \\
\hline $\mathrm{HF}_{2} \mathrm{COC}(\mathrm{O}) \mathrm{F}$ & NA & & & & \\
\hline $\mathrm{CF}_{3} \mathrm{OC}(\mathrm{O}) \mathrm{F}$ & NA & & & & \\
\hline $\mathrm{C}_{2} \mathrm{~F}_{5} \mathrm{OC}(\mathrm{O}) \mathrm{F}$ & NA & & & & \\
\hline $\mathrm{CF}_{3} \mathrm{CH}_{2} \mathrm{OC}(\mathrm{O}) \mathrm{F}$ & NA & & & & \\
\hline $\mathrm{CH}_{3} \mathrm{CF}_{2} \mathrm{OC}(\mathrm{O}) \mathrm{F}$ & NA & & & & \\
\hline $\mathrm{C}_{3} \mathrm{~F}_{7} \mathrm{OC}(\mathrm{O}) \mathrm{F}$ & NA & & & & \\
\hline $\mathrm{CF}_{3} \mathrm{C}(\mathrm{O}) \mathrm{OCH}_{3}$ & 0.33 & {$[14]$} & 97 & 28 & 8 \\
\hline $\mathrm{CF}_{3} \mathrm{C}(\mathrm{O}) \mathrm{OCF}_{3}$ & NA & & & & \\
\hline $\mathrm{CF}_{3} \mathrm{C}(\mathrm{O}) \mathrm{OCH}_{2} \mathrm{CH}_{3}$ & 0.06 & [14] & 10 & 3 & 1 \\
\hline $\mathrm{CF}_{3} \mathrm{C}(\mathrm{O}) \mathrm{OCH}_{2} \mathrm{CF}_{3}$ & 0.15 & [14] & 37 & 11 & 3 \\
\hline $\mathrm{CF}_{3} \mathrm{C}(\mathrm{O}) \mathrm{OCF}_{2} \mathrm{CF}_{3}$ & NA & & & & \\
\hline $\mathrm{CF}_{3} \mathrm{C}(\mathrm{O}) \mathrm{OCF}_{2} \mathrm{CH}_{3}$ & 0.33 & & 137 & 39 & 12 \\
\hline $\mathrm{CF}_{3} \mathrm{C}(\mathrm{O}) \mathrm{OCH}=\mathrm{CH}_{2}$ & NA & & & & \\
\hline $\mathrm{CF}_{3} \mathrm{C}(\mathrm{O}) \mathrm{OCH}_{2} \mathrm{CH}=\mathrm{CH}_{2}$ & NA & & & & \\
\hline $\mathrm{CF}_{3} \mathrm{C}(\mathrm{O}) \mathrm{OCH}\left(\mathrm{CF}_{3}\right)_{2}$ & NA & & & & \\
\hline $\mathrm{CF}_{3} \mathrm{C}(\mathrm{O}) \mathrm{OPh}$ & NA & & & & \\
\hline $\mathrm{CF}_{3} \mathrm{C}(\mathrm{O}) \mathrm{OCHF}_{2}$ & 0.30 & & 122 & 35 & 11 \\
\hline $\mathrm{HCF}_{2} \mathrm{C}(\mathrm{O}) \mathrm{OCH}_{3}$ & 0.11 & {$[14]$} & 19 & 5 & 2 \\
\hline $\mathrm{H}_{2} \mathrm{CFC}(\mathrm{O}) \mathrm{OCH}_{3}$ & NA & & & & \\
\hline $\mathrm{HCF}_{2} \mathrm{C}(\mathrm{O}) \mathrm{OCH}_{3}$ & NA & & & & \\
\hline $\mathrm{HCF}_{2} \mathrm{C}(\mathrm{O}) \mathrm{OCF}_{2} \mathrm{H}$ & NA & & & & \\
\hline
\end{tabular}


Table 4. Direct, indirect and net global warming potentials of some commons HFEs at time horizons of 20, 100 and 500 years. The parameters used for the calculation are also summarized here. The REs used for the HFEs were those reported in Table 2 applying the lifetime-dependent correction of Sihra et al. $(2001)^{[4]}$ to crudely account for incomplete vertical mixing. The REs used for the FESs where those reported in Table 2. For FESs we used the lifetimes of Table 3.

\begin{tabular}{|c|c|c|c|c|c|c|c|c|c|c|c|c|c|}
\hline \multirow{2}{*}{ HFE } & \multirow{2}{*}{ Lifetimes(yrs) / Ref } & \multirow[t]{2}{*}{ FES } & \multirow[t]{2}{*}{$\alpha$} & \multirow[t]{2}{*}{ Ref } & \multicolumn{3}{|c|}{ Indirect-GWP } & \multicolumn{3}{|c|}{ Direct-GWP } & \multicolumn{3}{|c|}{ Net-GWP } \\
\hline & & & & & 20 & 100 & 500 & 20 & 100 & 500 & 20 & 100 & $\mathbf{5 0 0}$ \\
\hline $\begin{array}{c}\mathrm{CF}_{3} \mathrm{OCH}_{3} \\
(\mathrm{HFE}-143 \mathrm{a}) \\
\end{array}$ & $4.3 /[27]$ & $\mathrm{CF}_{3} \mathrm{OC}(\mathrm{O}) \mathrm{H}$ & 1.00 & [30], [12] & 2620 & 745 & 226 & 1580 & 453 & 138 & 4200 & 1200 & 364 \\
\hline $\begin{array}{c}\mathrm{C}_{3} \mathrm{~F}_{7} \mathrm{OCH}_{3} \\
(\mathrm{HFE}-7000)\end{array}$ & $4.8 /[5]$ & $\mathrm{C}_{3} \mathrm{~F}_{7} \mathrm{OC}(\mathrm{O}) \mathrm{H}$ & 1.00 & {$[9]$} & 1580 & 463 & 140 & 1730 & 499 & 152 & 3310 & 962 & 292 \\
\hline $\begin{array}{c}\mathrm{C}_{2} \mathrm{~F}_{5} \mathrm{OCH}_{3} \\
(\mathrm{HFE}-245 \mathrm{cb} 2)\end{array}$ & $4.3 /[41]$ & $\mathrm{C}_{2} \mathrm{~F}_{5} \mathrm{OC}(\mathrm{O}) \mathrm{H}$ & 1.00 & {$[20]$} & 2520 & 745 & 226 & 2000 & 573 & 174 & 4520 & 1320 & 400 \\
\hline $\begin{array}{c}\mathrm{C}_{4} \mathrm{~F}_{9} \mathrm{OCH}_{3} \\
(\mathrm{HFE}-7100)\end{array}$ & $4.2 /[5]$ & $\mathrm{C}_{4} \mathrm{~F}_{9} \mathrm{OC}(\mathrm{O}) \mathrm{H}$ & 1.00 & {$[6]$} & 1570 & 458 & 139 & 1180 & 337 & 102 & 2750 & 795 & 241 \\
\hline $\begin{array}{l}\mathrm{C}_{4} \mathrm{~F}_{9} \mathrm{OC}_{2} \mathrm{H}_{5} \\
(\mathrm{HFE}-7200)\end{array}$ & $0.91 /[5]$ & $\begin{array}{c}\mathrm{C}_{4} \mathrm{~F}_{9} \mathrm{OC}(\mathrm{O}) \mathrm{H} \\
\mathrm{C}_{4} \mathrm{~F}_{9} \mathrm{OC}(\mathrm{O}) \mathrm{CH}_{3}\end{array}$ & $\begin{array}{l}0.20 \\
0.80 \\
\end{array}$ & [7] & 332 & 95 & 29 & 243 & 69 & 21 & 575 & 164 & 50 \\
\hline$\left(\mathrm{CF}_{3}\right)_{2} \mathrm{CHOCH}_{3}$ & $0.27 /[10]$ & $\begin{array}{c}\left(\mathrm{CF}_{3}\right)_{2} \mathrm{CHOC}(\mathrm{O}) \mathrm{H} \\
\mathrm{CF}_{3} \mathrm{C}(\mathrm{O}) \mathrm{OCH}_{3}\end{array}$ & $\begin{array}{l}0.66 \\
0.22 \\
\end{array}$ & {$[17]$} & 948 & 270 & 82 & 63 & 18 & 5 & 1010 & 288 & 87 \\
\hline $\mathrm{CF}_{3} \mathrm{CH}_{2} \mathrm{OCH}_{3}$ & $0.12 /[34]$ & $\begin{array}{c}\mathrm{CF}_{3} \mathrm{CH}_{2} \mathrm{OC}(\mathrm{O}) \mathrm{H} \\
\mathrm{CH}_{3} \mathrm{C}(\mathrm{O}) \mathrm{OCF}_{3}\end{array}$ & $\begin{array}{l}0.84 \\
0.16\end{array}$ & [34] & 199 & 57 & 17 & 21 & 6 & 2 & 220 & 63 & 19 \\
\hline $\mathrm{CF}_{3} \mathrm{CH}_{2} \mathrm{OCH}_{2} \mathrm{CF}_{3}$ & $0.22 /[10]$ & $\begin{array}{c}\mathrm{CF}_{3} \mathrm{C}(\mathrm{O}) \mathrm{OCH}_{2} \mathrm{CF}_{3} \\
\mathrm{CF}_{3} \mathrm{CH}_{2} \mathrm{OC}(\mathrm{O}) \mathrm{H}\end{array}$ & $\begin{array}{l}0.15 \\
0.85\end{array}$ & $\begin{array}{l}{[10]} \\
{[32]}\end{array}$ & 133 & 38 & 11 & 55 & 16 & 5 & 188 & 54 & 16 \\
\hline $\mathrm{CF}_{3} \mathrm{CHClOCHF}_{2}$ & $3.2 /[40]$ & $\mathrm{CF}_{3} \mathrm{C}(\mathrm{O}) \mathrm{OCHF}_{2}$ & 0.85 & {$[18]$} & 148 & 148 & 13 & 1510 & 429 & 130 & 1660 & 577 & 143 \\
\hline
\end{tabular}




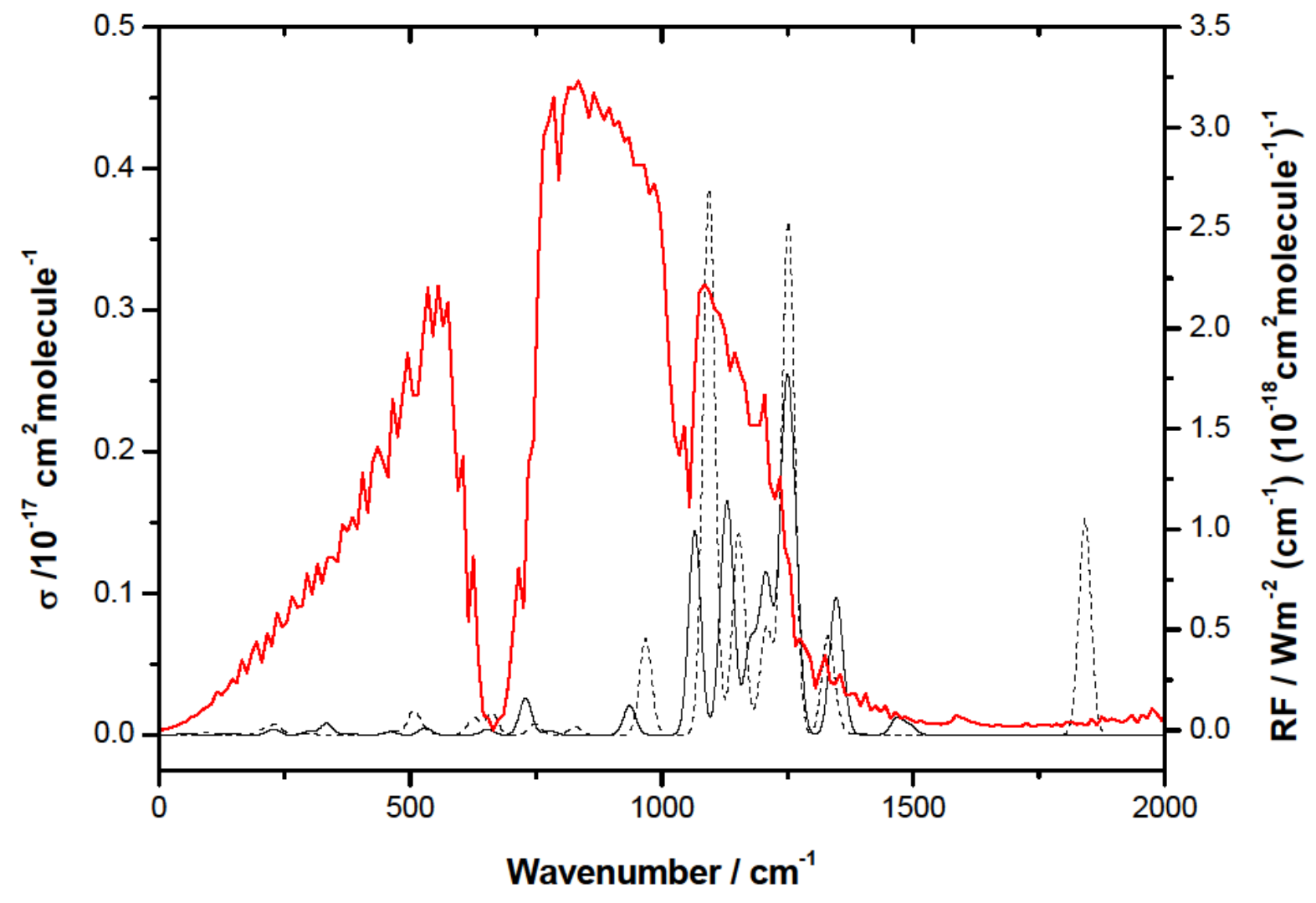

Figure 1. Calculated infrared spectra of $\mathrm{CF}_{3} \mathrm{OCF}_{2} \mathrm{CF}_{2} \mathrm{CF}_{3}(\mathrm{HFE}-7000)$ and $\mathrm{HC}(\mathrm{O}) \mathrm{OCF}_{2} \mathrm{CF}_{2} \mathrm{CF}_{3}$ are represented using solid and dashed curves, respectively. The calculated modes were convoluted with Gaussian functions of 14 $\mathrm{cm}^{-1}$ full width. The radiative forcing function used in the Pinnock et al. (1995) [23] model is represented in red curve. 


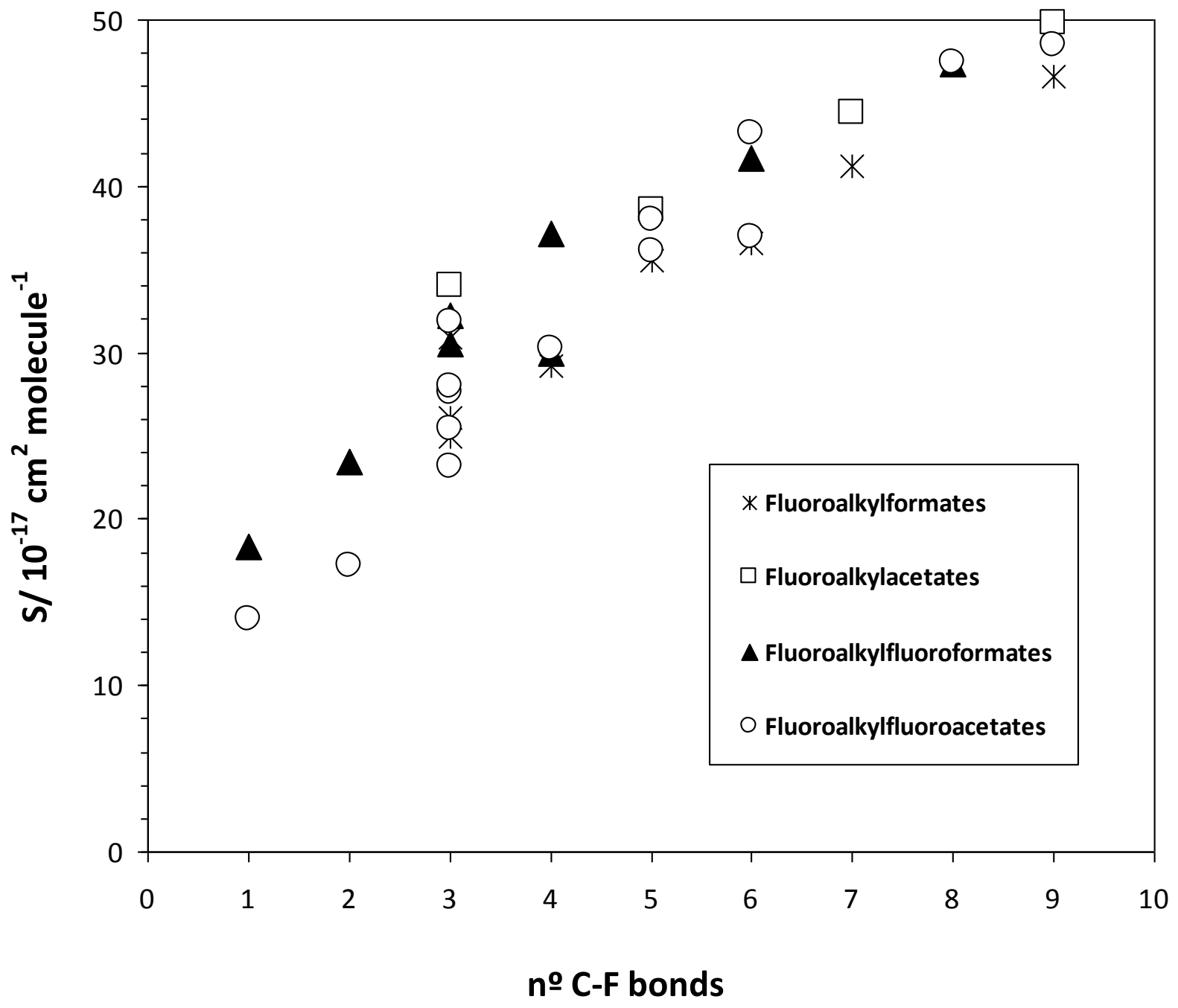

Figure 2. Plot of integrated cross section values, S, for computational B3LYP/6-31G** method versus the number of C-F bonds for the studied FESs. Data are taken from Table 1. 


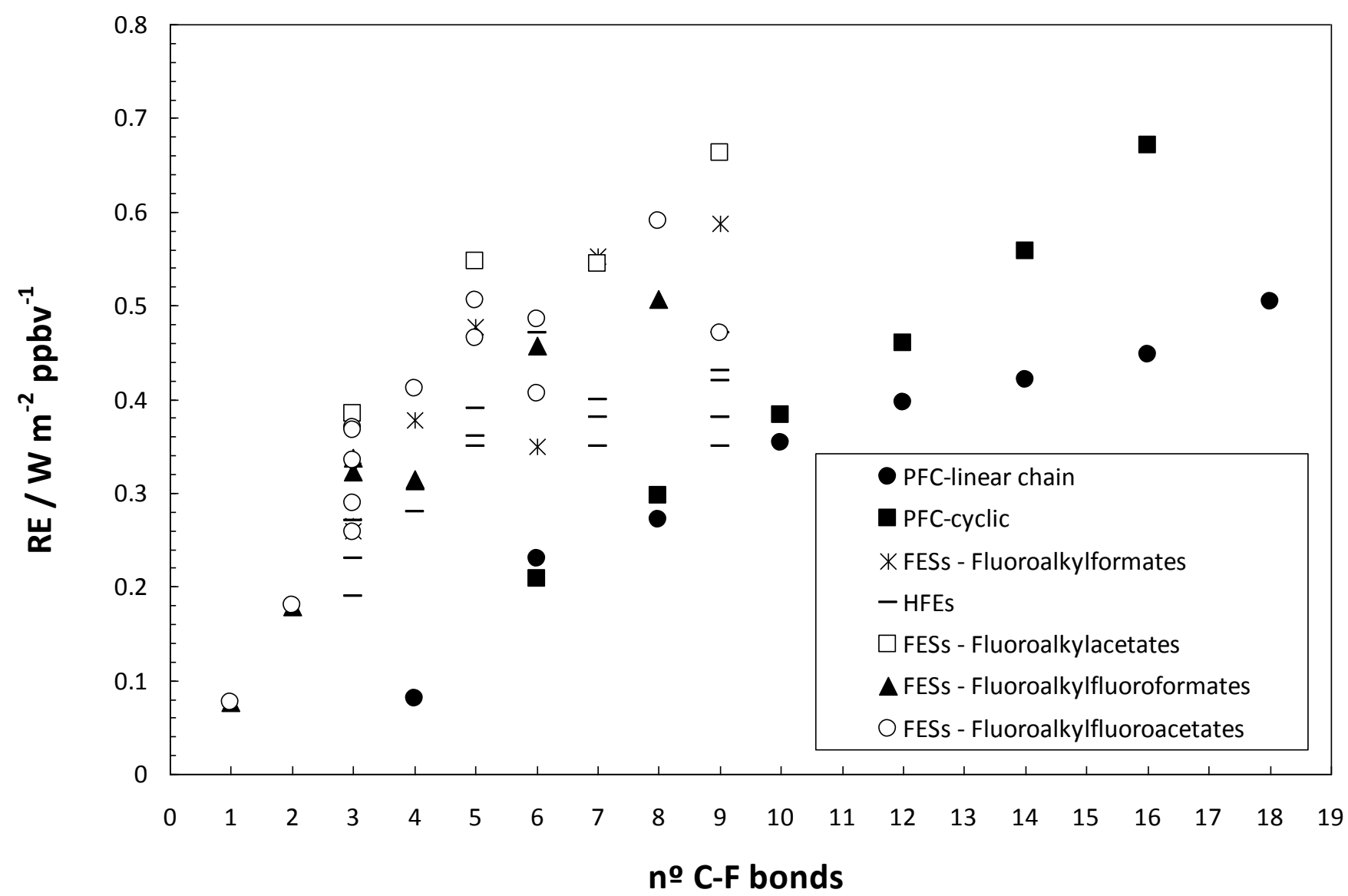

Figure 3. Plot of radiative efficiency values for the studied set of FESs versus the number of C-F bonds and comparison with PFCs (linear chain, cyclic and branched) and HFEs. 

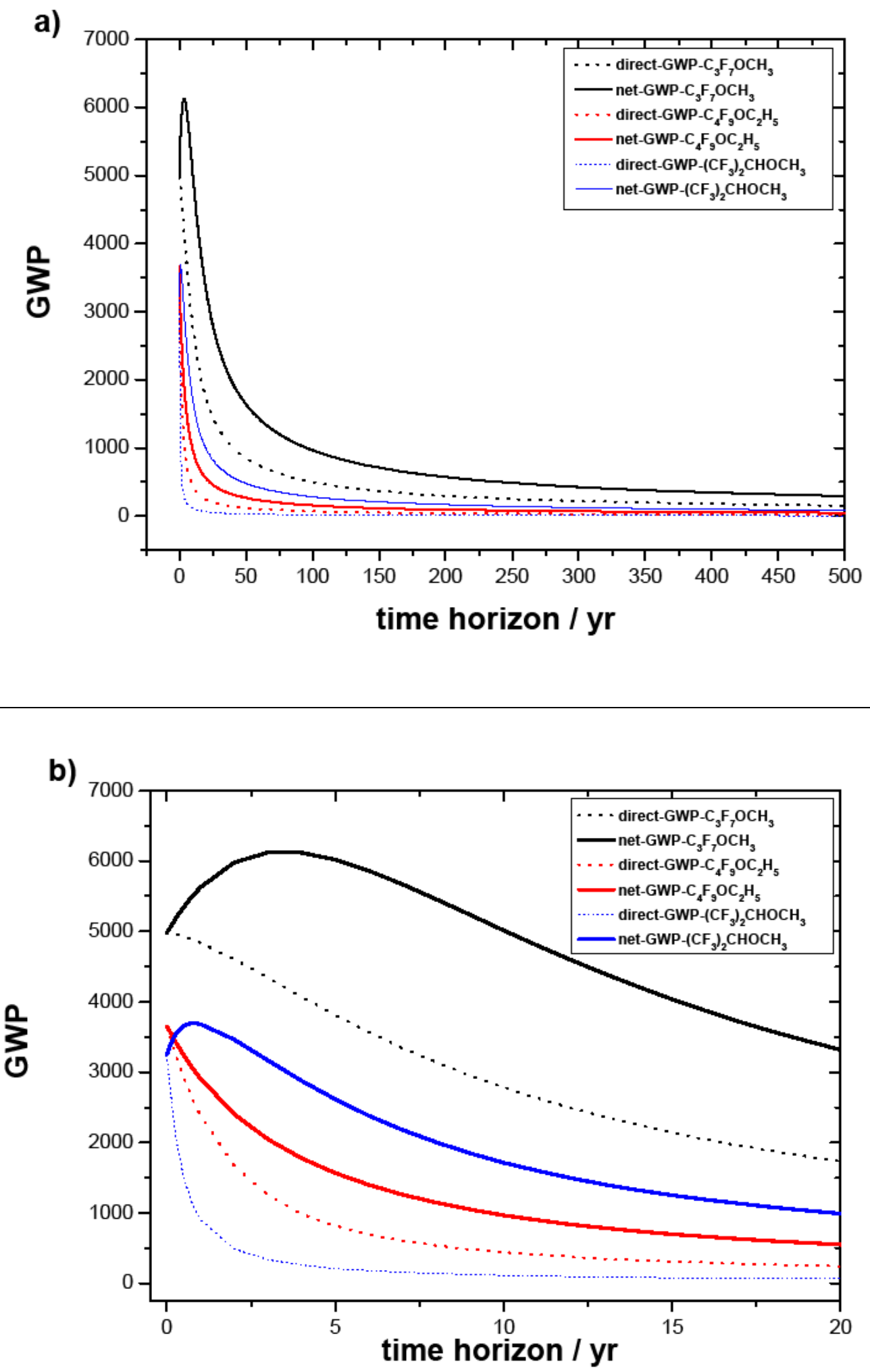

Figure 4. Plot of indirect, direct and net-GWP for HFE-7000 $\left(\mathrm{C}_{3} \mathrm{~F}_{7} \mathrm{OCH}_{3}\right), \mathrm{HFE}-7200\left(\mathrm{C}_{4} \mathrm{~F}_{9} \mathrm{OC}_{2} \mathrm{H}_{5}\right)$ and $\left(\mathrm{CF}_{3}\right)_{2} \mathrm{CHOCH}_{3}$ versus the time horizon at different ranges: a) 0-20 yrs; b) 0-500 yrs. Parameters used for this plot are summarized in Table 4. 